\title{
The mechanisms and managements of hormone-therapy resistance in breast and prostate cancers
}

\author{
K-M Rau ${ }^{1,2 *}, H-Y K^{2}{ }^{3,4 *}, T-L C h a^{1,5,6}, S$ A Miller ${ }^{1}$ and M-C Hung ${ }^{1}$ \\ ${ }^{1}$ Department of Molecular and Cellular Oncology, The University of Texas M.D. Anderson Cancer Center, Houston, TX 77030, USA \\ ${ }^{2}$ Department of Hematology-Oncology, Chang Gung Memorial Hospital, Kaohsiung Medical Center, Kaohsiung, Taiwan \\ ${ }^{3}$ Graduate Institute of Clinical Medical Sciences, Chang Gung University, Kaohsiung, Taiwan \\ ${ }^{4}$ The Center for Menopause and Reproductive Medicine Research, Chang Gung Memorial Hospital, Kaohsiung Medical Center, \\ Kaohsiung, Taiwan \\ ${ }^{5}$ Graduate School of Biomedical Sciences, The University of Texas Health Science Center at Houston, Houston, TX 77030, USA \\ ${ }^{6}$ Division of Urology, Department of Surgery, Tri-Service General Hospital, National Defense Medical Center, Taipei, Taiwan \\ (Requests for offprints should be addressed to M-C Hung; Email: mhung@mail.mdanderson.org) \\ *(K-M Rau and H-Y Kang contributed equally to this work)
}

\begin{abstract}
Breast and prostate cancer are the most well-characterized cancers of the type that have their development and growth controlled by the endocrine system. These cancers are the leading causes of cancer death in women and men, respectively, in the United States. Being hormone-dependent tumors, antihormone therapies usually are effective in prevention and treatment. However, the emergence of resistance is common, especially for locally advanced tumors and metastatic tumors, in which case resistance is predictable. The phenotypes of these resistant tumors include receptorpositive, ligand-dependent; receptor-positive, ligand-independent; and receptor-negative, ligandindependent. The underlying mechanisms of these phenotypes are complicated, involving not only sex hormones and sex hormone receptors, but also several growth factors and growth factor receptors, with different signaling pathways existing alone or together, and with each pathway possibly linking to one another. In this review, we will discuss the potential mechanisms of antihormonetherapy resistance in breast and prostate cancers, especially focusing on the similarities and differences of these two cancers. We will also discuss novel agents that have been applied in clinical practice or with clinical potential in the future.
\end{abstract}

Endocrine-Related Cancer (2005) 12 511-532

\section{Introduction}

The endocrine system is critical for growth, maturation, and coordination of the human body. However, malignancies can also arise from the organs influenced by endocrine-system-secreted hormones. Among these malignancies, the most widely studied are breast cancer and prostate cancer. Apart from skin cancers, breast cancer and prostate cancer are the primary diagnosed cancer and secondary cause of cancer death in women and men, respectively, in the United States (Jemal et al. 2004). These two types of cancer are not only similar in their epidemiological patterns but also possess similar pathological entities. Both of them are hormonerelated cancers. They depend on specific steroid hormone receptors, such as estrogen receptor (ER), progesterone receptor (PR), and androgen receptor (AR), to mediate hormone effects on the initiation and progression of diseases. With the improvement of diagnostic methodologies, the incidence of both cancer types have increased, which is most likely attributed to early diagnosis, but the cancer death rate of breast and prostate cancers has continued to decline since 1992 and 1995, respectively (Jemal et al. 2003). However, to date curative treatments for both advanced cancers have not yet been established. Understanding the underlying pathogenesis of disease progression is the pivotal prerequisite for developing effective therapeutic and preventive strategies of these two cancers.

Since ER and AR mediate the hormone effect on tumor initiation and progression in breast and prostate cancer, several selective ER modulators (SERMs; 
Katzenellenbogen and Katzenellenbogen 2002, Jordan $2003 a, 2003 b$ ) and selective AR modulators (SARMs) that specifically inhibit receptor function by means of hormone deprivation or hormone blockade have been applied in clinics as both therapeutic and preventive strategies. Tamoxifen (TAM), the most commonly used SERM, competes with estrogen having a higher binding affinity to ER. Although TAM-binding ER can also translocate into the nucleus, the TAM-ER transcription complex is incomplete and insufficient to initiate downstream target gene transcription which is required for estrogen-dependent tumor growth (Piccart et al. 2003). Flutamide (FLU) and bicalutamide are both pure antiandrogen agents; they inhibit androgen from binding to AR and its subsequent translocation (Brogden \& Chrisp 1991). In order to get maximal androgen blockade, antiandrogen agents usually combine gonadotropin-releasing hormone $(\mathrm{GnRH})$ agonist to suppress the compensatory-elevated luteinizing hormone (LH) and follicular-stimulating hormone (FSH; Labrie et al. 1993).

About $75 \%$ of breast cancer patients are ER- or PR-positive. TAM is the most frequently used drug as an adjuvant therapy for ER- and/or PR-positive breast cancer patients (Kiang \& Kennedy 1977, Early Breast Cancer Trialists' Collaborative Group 1998, Fisher et al. 1998, Schiff et al. 2000).

After a 5-year administration of adjuvant TAM, the proportional recurrence reduction was $47 \%$, and the corresponding mortality reduction was $26 \%$ (Early Breast Cancer Trialists' Collaborative Group 1998). TAM can also be used as a first-line therapy for metastatic breast cancer patients if their tumors are hormone receptor-positive and can be used as a chemoprevention agent for high-risk patients (Fisher et al. 1998). Although TAM is effective as an adjuvant and chemopreventive agent, there is still a significant proportion of patients who develop breast cancer or relapse breast cancer even after taking TAM, and the emergence of resistance in metastatic breast cancers is usually not preventable (Muss 1992). In prostate cancer, the majority of cases are AR-positive and androgenablation therapy by surgery, medicine, or combination is mandatory to those patients with locally advanced prostate cancer or metastatic disease. However, the response to hormone therapy is temporary and relapse is eventually inevitable. Chemoprevention is considered to be particularly important to reduce incidence of prostate cancer because of its diagnosis in elderly men, and even a modest delay in the neoplastic development could result in a substantial reduction in the incidence of this clinically detectable disease. Unlike breast cancer, chemoprevention for prostate cancer has just emerged and under evaluation. A recent prostate cancer prevention trial has been done to show that finasteride, a $5 \alpha$-reducatase inhibitor that inhibits the conversion of testosterone to a more potent androgen, dihydrotestosterone, has a chemopreventive effect for prostate cancer development (Thompson et al. 2003). However, in this study they point out that finasteride also increases the risk of high-grade prostate cancer. This result implies that hormone deprivation for prostate cancer may promote the phenotypic progression of those tumor cells that are able to survive the acute period of the therapy. The selection pressure driven by hormone therapy seems play the same roles in both breast and prostate cancer.

The phenotypes of these resistant/relapsed tumors can be roughly categorized into: (1) receptor-positive, hormone-dependent, but resistant to or even stimulated by the first-line antihormone agents; (2) receptorpositive, hormone-independent; and (3) receptornegative, hormone-independent. Several mechanisms have been proposed for these phenotypes. However, a common scenario is that once the tumor develops resistance to antihormone therapy it will become more aggressive and correlate with poor prognosis. Therefore understanding the mechanism of resistance emergence and the methods to overcome the resistance is critical for the treatment of hormone-therapyresistant tumors. In this review, we will discuss the similarities and differences between breast cancer and prostate cancer in the development of hormone resistance and the therapeutic options (Table 1).

\section{Sex hormone - sex hormone receptor-modulating mechanisms}

In human beings, secretion of sex hormones is controlled by the hypothalamus-pituitary-sex gland axis. For premenopausal women, ovaries produce almost all of the estrogen, and the primary estrogen produced is $17 \beta$-estradiol; for postmenopausal women, peripheral tissues, such as the adrenal gland, peripheral adipose tissue, and even the breast itself are the main organs producing estrogen. In men, the testes produce the majority of circulating testosterone, which is converted into the more powerful dihydrotestosterone (DHT) by $5 \alpha$-reductase in target organs. A small portion of testosterone is produced by adrenal glands. Although the secretion of testosterone will decrease during aging, testes are still the major source of androgen in the elderly (Table 2).

Both ER and AR belong to the steroid nuclear receptor superfamily. The basic domain structures of 
Table 1 Resistance mechanism and corresponding therapeutic countermeasures

\begin{tabular}{|c|c|c|c|}
\hline Receptor & $\begin{array}{c}\text { Ligand } \\
\text { dependence }\end{array}$ & Resistance mechanism & Therapeutic countermeasures \\
\hline ER-/AR-positive & Positive & $\begin{array}{l}\text { Receptor amplification } \\
\text { Increased circulating hormone } \\
\text { Increased endogenous hormone } \\
\text { Receptor hypersensitivity } \\
\text { Changing ratio of coregulators }\end{array}$ & $\begin{array}{l}\text { Total hormone ablation by antihormone agent } \\
\quad \text { and GnRH agonist } \\
\text { Aromatase inhibitor }(\mathrm{BC}) \\
\text { Fulvestrant }(\mathrm{BC}) \\
\text { MAPK-pathway inhibitors } \\
\text { Chemotherapy } \\
\text { SERM } \\
\text { SARM }\end{array}$ \\
\hline ER-/AR-positive & Negative & $\begin{array}{l}\text { Receptor mutation } \\
\text { Crosstalk with other growth } \\
\text { factors and receptors } \\
\text { and receptors } \\
\text { Bypass receptors }\end{array}$ & $\begin{array}{l}\text { Hsp90 inhibitor } \\
\text { Anti-EGFR antibodies (IMC-C225, ABX-EGF) } \\
\text { Anti-Her-2 antibodies (trastuzumab, 2C4) } \\
\text { Tyrosine kinase inhibitors } \\
\quad \text { (gefitinib, OSI-774, Cl-1033, PKI166, GW572016) } \\
\text { Emodin } \\
\text { E1A } \\
\text { Bcl-2 antisense } \\
\text { Chemotherapy }\end{array}$ \\
\hline ER-/AR-negative & Negative & Loss of receptors & Chemotherapy \\
\hline
\end{tabular}

BC, breast cancer; EFGR, epidermal growth factor receptor; Hsp, heat-shock protein; MAPK, mitogen-activated protein kinase.

Table 2 The major hormone source and antihormone therapy agents of breast cancer and prostate cancer

\begin{tabular}{lll}
\hline & Breast cancer & Prostate cancer \\
\hline Major sex hormone & $17 \beta$-Estradiol & DHT \\
Major source of sex hormone & Premenopause: ovary & Majority: testis \\
& Postmenopause: peripheral adipose & Minority: adrenal gland \\
First-line antihormone agents & tissue, adrenal gland, breast & FLU \\
Chemoprevention agents & TAM & GnRH agonist \\
& Aromatase inhibitor & Finasteride \\
\hline
\end{tabular}

the nuclear receptor superfamily include an $\mathrm{N}$-terminal region with the activation function 1 (AF-1) domain, a DNA-binding domain (DBD) with two zinc-finger structures, and a hinge region and ligand-binding domain (LBD) at the C-terminus (Fu et al. 2003). The LBD includes the activation function 2 (AF-2) domain and $12 \alpha$-helices that project away from the hormonebinding groove in the absence of ligand. Without ligand binding, ER/AR associates with chaperone proteins, heat-shock proteins (Hsps), and the immunophilin complex. After ligand binding, receptors dissociate from chaperone proteins, and form homodimers or heterodimers that can bind to the estrogen- and androgenresponse elements in the promoter regions of target genes. This will release corepressors and recruit coactivators, thereby forming a transcriptional complex and initiating target gene transcription (Feldman \& Feldman 2001, Osborne et al. 2001, Isaacs et al. 2003)

There are two ER genes on different chromosomes, ER- $\alpha$ on chromosome $6 \mathrm{q} 25.1$, and ER- $\beta$ on chromosome $14 \mathrm{q} 22-25$. ER- $\alpha$ is usually the dominant isoform and correlates with most of the prognostic factors in breast cancers (Fuqua et al. 2003). Both proteins have compatible binding affinities for estradiol and similar binding domains for ligand and DNA; they also have two transcriptional domains, AF-1 and AF-2. The transcriptional function of AF-1 and AF-2 is tissueand promoter-specific. The transcription function of AF-1 is ligand-independent, and it is closely related to the phosphorylation status of ER, and can be induced by mitogen-activated protein kinases (MAPKs), growth factors and oncogenes (Fu et al. 2003), while 
AF-2 is completely ligand-dependent (Kato et al. 2000). AF-1 and AF-2 of ER can activate transcription independently or synergistically. ER- $\alpha$ and ER- $\beta$ have opposite effects on transcription initiated by AP-1, SP-1, or cAMP-response elements (CREs; Paech et al. 1997, Castro-Rivera et al. 2001, Liu et al. 2002). Especially in a low-estrogen environment such as in cases of aromatase-inhibitor treatment, the inhibitory effect of ER- $\beta$ could become more prominent as an antitumor mechanism (Jordan 2003a). Thus compounds that are antagonists for ER- $\alpha$ may be agonists for ER- $\beta$ at these sites. However, the function and prognostic significance of ER- $\beta$ is still not clear (Hall \& McDonnell 1999, Palmieri et al. 2004, Speirs et al. 2004). For those breast cancer cells with ER expression, the ratio between ER- $\alpha$ and ER- $\beta$ may change during carcinogenesis, it may also serve as an important marker in predicting the response to certain kinds of specific selective estrogen-modulator therapy (Dotzlaw et al. 1999). In contrast to ER, no AR isoform has been found to date. Without ligand binding, ER mainly stays in nucleus but the majority of AR stays in cytoplasm. Upon ligand binding, the AR homodimer will translocate into the nucleus. In addition, androgens can stabilize AR protein level 6-fold compared to the level without ligand binding. However, estrogen binding will accelerate ER degradation. These biological differences between ER and AR could be used as different targeting strategies (Table 3).

\section{Mechanisms of resistance}

There are several mechanisms that have been proposed to be responsible for the emergence of hormone resistance in breast cancers and prostate cancers. These resistance mechanisms can occur at the pre-receptor level, such as a change in the hormone level, at the receptor level, or at the post-receptor level. Based on the three major phenotypes mentioned above, we summarize several possible mechanisms for the development of resistance (Figure 1). These events can occur alone or together, dependent on the individual case, and therefore the next step of therapy after the emergence of resistance should depend on the underlying mechanism for the resistance.

\section{Receptor-positive, ligand-dependent}

\section{Enhancing receptor expression}

Long-term hormone deprivation may select for cancer cell clones that enhance the expression of receptors to compensate for the low-level ligand environment. In long-term estrogen deprivation of MCF-7 cells, ER- $\alpha$ was found to be upregulated 4-10-fold (Santen et al. 2003). The same situation was reported for ER- $\beta$ from clinical samples (Speirs et al. 1999). In prostate cancer AR gene amplification is rarely found in primary cancer; after androgen-ablation therapy, approximately $30 \%$ of tumors become androgen independent due to an increase of AR expression (Feldman \& Feldman 2001). Additionally, the gain of AR gene copies in primary prostate cancer due to X-chromosome polysomy was observed (Ropke et al. 2004). This may due to the selective effect that comes from the low level of androgen after androgen ablation, which favors clonal expansion of cancer cells expressing a higher level of AR. These tumors are still hormone-dependent, and they may respond to second-line therapy with total hormone ablation.

\section{Increased circulating hormone}

TAM binds to ER, and FLU binds to AR to antagonize sex hormones in the tumors; however, they also bind to the receptors in pituitary gland and hypothalamus, which may interrupt the negative-feedback pathways of sex hormones. As a result GnRH is secreted continuously, ultimately producing a hyperstimulatory effect on the ovaries or testes resulting in oversecretion of estrogen or androgen. This may explain the elevated estradiol levels that were noted in some premenopausal breast cancer patients after TAM administration (Ravdin et al. 1988). To overcome this problem, GnRH analogues can be combined with antihormone agents to reach total estrogen or androgen ablation (Robertson \& Blamey 2003).

Table 3 Comparison of ER and AR

\begin{tabular}{lll}
\hline & ER & AR \\
\hline Expression before treatment & $75 \%$ & $>90 \%$ \\
Mutation as the cause of resistance & $<10 \%$ & $30 \%$ \\
Location before ligand binding & Nucleus & Cytoplasm \\
Isoform & ER- $\alpha /$ ER- $\beta$ & No isoform \\
Dimer formation after ligand binding & Homo-/heterodimer & Homodimer only \\
Stability after ligand binding & Accelerated degradation & More stable \\
\hline
\end{tabular}




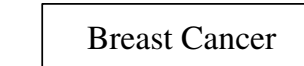

(E) $\uparrow$ Circulating estrogen level

\section{Prostate Cancer}

A $\uparrow$ Intracellular androgen

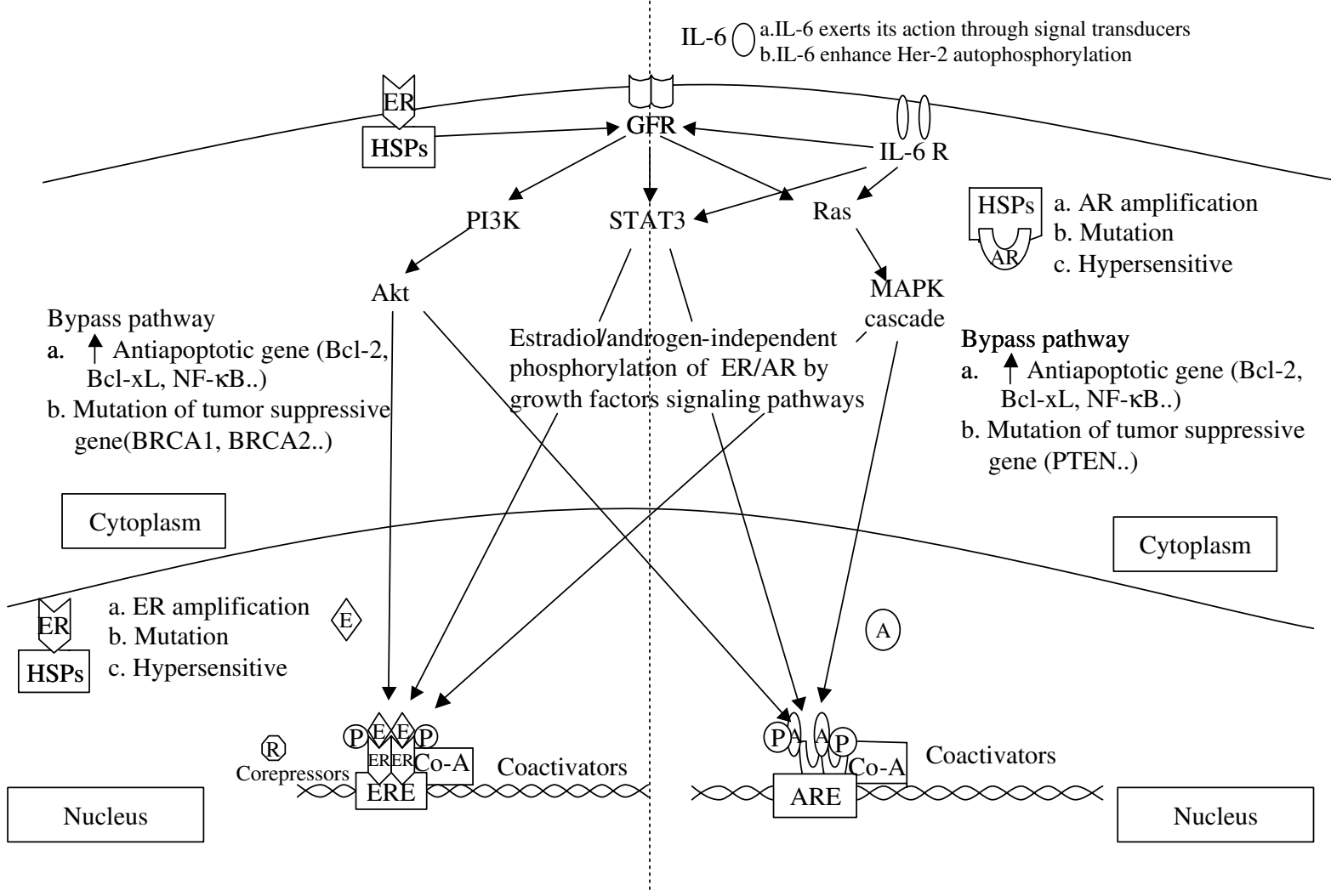

Figure 1 Summary of several mechanisms that have been proposed to be responsible for the emergence of hormone resistance in breast cancers and prostate cancers. These mechanisms make up the three phenotypes. A androgen, AR androgen receptor, ARE androgen responsive element, Co-A coactivator, E estrogen, ER estrogen receptor, ERE estrogen responsive element, GFR growth factor receptor, IL-6 interleukin 6, IL-6R interleukin 6 receptor, PI-3K phosphatidylinositol 3-kinase, R corepressor, STAT3 signal transducer and activator of transcription 3.

\section{Increased endogenous hormone}

In females, estrogen production can be converted from androgen by aromatase in the breast. The transcriptional control of aromatase is different between normal tissue and breast cancer tissue (Harada et al. 1993). Increased aromatase expression and activity have been noted in breast tumors compared to peritumor tissues (Goss \& Strasser 2002). This increased production of aromatase comes from the interaction between breast cancer cells and associated fibroblasts and inflammatory cells in the adjacent stroma. Breast cancer cells synthesize prostaglandin $\mathrm{E}_{2}$, and inflammatory cells produce not only prostaglandin $\mathrm{E}_{2}$ but also interleukin 6 (IL-6), IL-11, and tumor necrosis factor $\alpha$ (TNF $\alpha$ ), all of which stimulate fibroblasts to produce aromatase. This mechanism is related closely to cyclooxygenase 2 (COX-2; Johnston \& Dowsett 2003). Also in long-term estrogen-deprived breast cancer cells, aromatase activity increases adaptively (Yue et al. 1999). Both of these cases lead to higher local estrogen concentration and can overcome the effect of anti-estrogen agents. This may explain in part why aromatase inhibitors elicit a better clinical response than TAM in clinical studies (Wong \& Ellis 2004).

In males, long-term androgen-ablation therapy may select prostate cancer cells with higher $5 \alpha$-reductase activity, which can produce more DHT from adrenal androgen, thus providing a higher intracellular DHT level to compensate for the low level of circulating testosterone (Navarro et al. 2002). Men of African descent, who have the highest incidence of a polymorphism in the gene of $5 \alpha$-reductase in which a valine residue at codon 89 is substituted by a leucine, have been reported to have higher $5 \alpha$-reductase activity and 
have a particularly high incidence of prostate cancer with poor prognosis (Ruijter et al. 1999).

\section{Receptor hypersensitivity}

Receptors may have congenital or acquired mutations that change their sensitivity to ligands. A study of a typical breast hyperplasia found that a mutation of ER- $\alpha$ (Ala-908 $\rightarrow$ Gly) affects the border of the hinge and hormone-binding domains of ER- $\alpha$ and shows increased sensitivity to estrogen. This mutation may promote or accelerate the development of cancer from premalignant breast lesions (Fuqua et al. 2000). Longterm deprivation of estrogen, for instance with TAM treatment, can induce hypersensitivity of breast cancer cells to estradiol (Berstein et al. 2004). Such adaptive hypersensitivity may go through a rapid, nongenomic plasma membrane receptor-mediated pathway: estradiol binds to ER- $\alpha$, then phosphorylates Shc, Shc then binds to Grb-2 and SoS, resulting in the rapid activation of MAPK through Ras, Raf, and MAPK/ extracellular-signal-regulated kinase (ERK) kinase (MEK), and then the phosphorylation of AF-1 on ER- $\alpha$ (Santen et al. 2003). Several agents can block this pathway, including: aromatase inhibitors, which block the estrogen production from the peripheral tissue; the pure anti-estrogen fulvestrant (Howell 2001); farnesylthiosalicylic acid, an inhibitor of GTP-Ras binding to its membrane acceptor site (Berstein et al. 2003); and the MEK inhibitor U0126 (Martin et al. 2003).

Upregulation of AR sensitivity to low-level androgen was also found in a prostate cancer animal model (Gregory et al. 2001 b). Under androgen-ablation conditions, AR from the recurrent prostate cancer was highly expressed, with increased stability and nuclear localization, making the tumor cells more sensitive to the growth-promoting effect of DHT. The concentration of DHT needed for growth stimulation was four orders of magnitude lower in androgen-independent prostate cancer (AIPC) cells than in androgendependent LNCaP cells. Also chronic activation of Ras/MAPK signaling could cause or contribute to the development of AIPC cells (Bakin et al. 2003).

\section{Coregulator regulation in breast and prostate cancers}

In recent years a large number of nuclear and steroid receptor coregulators, including coactivators and corepressors, have been cloned and characterized to regulate receptor-mediated transactivation. After ligands bind their receptors, these coregulators are recruited to the promoters of target genes through protein - protein interaction, enhancing or reducing the nuclear receptor-mediated transcription of responsive genes (Klinge 2000). Coactivators are protein complexes with intrinsic histone acetyltransferase activity that affect transcription by modifying the chromatin structure in a ligand-dependent manner; corepressors are proteins associated with unligated nuclear receptors that recruit histone deacetylase complexes and inhibit transcription. The extent and direction of transcription of responsive genes are influenced not only by the types of ligands, but also by specific coregulators. The ratio of coactivators to corepressors may also determine the direction of gene transcription. As shown in Table 4, many coactivators have been identified as enhancing the ligand-induced transcriptional activity for both AR and ER. The most wellcharacterized is the steroid receptor coactivator (SRC) family, which contains SRC-1, transcriptional intermediary factor 2 (TIF2), and Amplified in Breast Cancer (AIB1)/SRC-3. Members of the SRC family of coactivators typically interact with the LBD of nuclear receptors through LXXLL motifs (where $\mathrm{L}$ is leucine and $X$ is any amino acid) that form $\alpha$-helices. The LXXLL domains of the coactivators interact with the nuclear receptor partly through the hydrophobic surface of the receptor AF-2 domain. The ER dimer binds to SRC-1 through an interaction between the ER LBD and the LXXLL motifs of SRC-1. SRC-1 and TIF-2 interact primarily with the AR N-terminus and possibly the DBD and this interaction, in contrast to several other nuclear receptors, does not require the coactivators to contact intact LXXLL motifs (Spencer et al. 1997, Bevan et al. 1999, He et al. 1999). Although the crystal structure of AR suggests that ligandbinding induced LBD conformations similar to ER and potentially generates a similar coregulator interaction surface, functional analyses of the full-length receptors suggest that distinct differences exist between the coregulator interaction domains of AR and ER. This may be because the interaction between the AR $\mathrm{N}$-terminus and the LBD generates a potential coregulator in interaction structure that differs from that of ER. Since different target cells express different levels of coactivators and corepressors, which accounts for cell-specific regulation of responsive gene expression, increased activity of coactivators can lead to the emergence of resistance. Additionally, coactivators can interact with other transcriptional factors (Lee et al. 1998), and as a result they also enhance transcription without ligand binding. Several coactivators are important both in breast cancer and prostate cancer for the development of hormone independence. Disruption of SRC-1 results in partial hormone resistance, particularly to thyroid hormone (Xu et al. 1998). In 


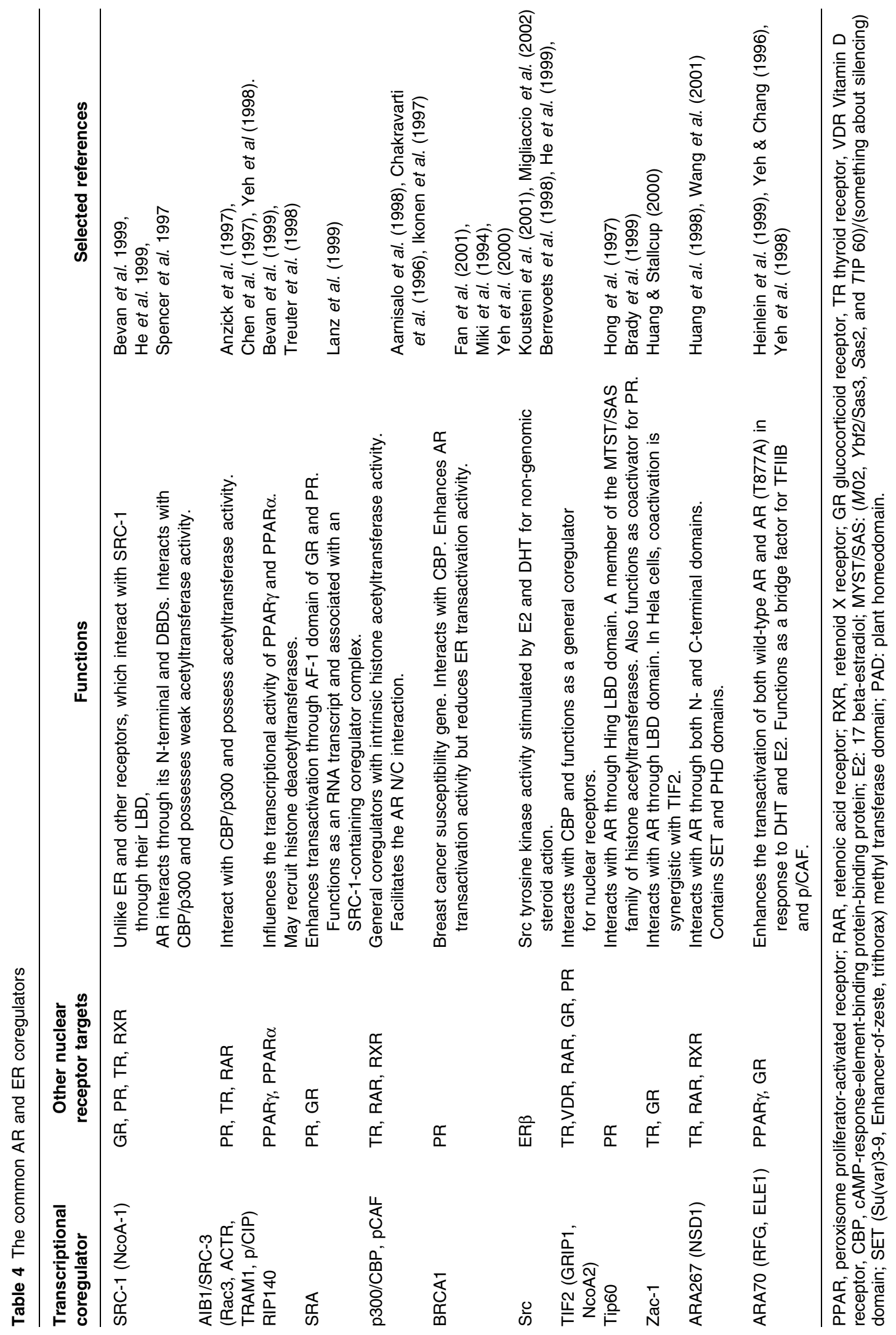


addition, results from different groups indicated that SRC-1 is involved in the progression of prostate cancers. Using reverse transcriptase PCR, Fujimoto and colleagues (2001) found that the expression levels of SRC-1 were higher in higher-grade prostate cancers or cancers with a poor response to endocrine therapy. At the same time, it has been reported that SRC-1 expression was elevated, together with the expression of AR, in recurrent prostate cancers (Gregory et al. 2001a). Previous studies found that SRC-2 is also overexpressed in recurrent prostate cancers. Overexpression of SRC-1 and SRC-2 confers on AR an increased sensitivity to the growth-stimulating effects of low-androgen concentrations. This change may contribute to prostate cancer recurrence after androgen-deprivation therapy. High levels of SRC-1 in uterus and breast are known to enhance the agonistic effect of TAM (Katzenellenbogen \& Katzenellenbogen 2002); SRC-1 can also interact synergistically with CRE-binding protein to activate ER-mediated transcription in a ligand-independent manner (Jackson et al. 1997), and this activity can be inhibited by corepressor SMRT (Smith et al. 1997).

In TAM-treated breast cancer patients, high AIB1/ SRC-3 expression was associated with worse diseasefree survival, which is indicative of TAM resistance (Osborne et al. 2003). Compared with the widespread expression of SRC-1 and SRC-2, expression of AIB1/ SRC-3 is restricted to few tissues, including the uterus, the mammary gland and the testis (Suen et al. 1998). Disruption of AIB1/SRC-3 gene in mice causes severe growth and reproductive defects, such as the retardation of mammary gland development (Xu et al. 2000). Amplification and overexpression of AIB1/SRC-3 in human breast and ovarian cancers have been observed (Anzick et al. 1997, Chen et al. 1997, Yeh et al. 1998). It has been reported that the AIB1/SRC-3 amplification/overexpression was correlated with ER and PR positivity (Bautista et al. 1998).

Breast cancer (BRCA1) is a breast cancersusceptibility gene, and its mutations are correlated with an increased risk of breast and ovarian cancers (Martin et al. 2001). Interestingly, BRCA1 was shown to function as a ligand-independent corepressor for ER and PR and enhance the ligand-dependent AR transactivation in the presence of exogenous SRC family members (Miki et al. 1994, Yeh et al. 2000, Fan et al. 2001). Thus, it is reasonable to speculate that the normal expression of BRCA1 probably protects the breast from tumorigenesis by suppressing the ER and PR signaling pathway and promoting AR activity in prostate cancer development. The ARAs, AR-associated proteins, is a group of factors that can bind to AR and modulate its transcriptional activity. Based on their molecular masses, these factors were named ARA70, ARA160, ARA54, ARA55, ARA267 and ARA24 (Kang et al. 1999, Yeh et al. 1999). Studies on the expression patterns of ARA70 in different cell lines and human cancer samples showed that the expression of ARA70 was decreased in prostate cancer (Yeh et al. 1999) and breast cancer (Kollara et al. 2001). In breast, loss of ARA70 protein expression was found in $60 \%$ of Human Epidermal growth factor receptor (HER)2positive breast cancers, whereas only $33 \%$ of HER2negative breast cancer samples lost the expression (Kollara et al. 2001). Since androgen plays an inhibitory role for breast cancer cell growth, and HER2 stimulates the growth of breast cancers, loss of the expression of AR and/or ARA70 in breast might confer a growth advantage to these cells. In prostate, ARA70 mRNA is highly expressed in the normal epithelial cells, while benign prostatic hyperplasic and cancer cell lines express either lower or no ARA70 (Kollara et al. 2001).

\section{Receptor-positive, ligand-independent}

\section{Receptor mutations}

Mutations of receptors can occur during the initiation of tumor formation, or can develop after therapy begins. Mutations in the ligand-binding domains of receptors may change not only their binding affinity and sensitivity to circulating ligands, but also the specificity of the receptors to their ligands. In this case receptors are able to bind substitutes such as other circulating steroid hormones, or even antihormone agents such as TAM or FLU to stimulate cell growth.

In breast cancer, ER mutation is not a major cause of hormone resistance since it is seen in fewer than $10 \%$ of TAM-resistant breast cancer patients (Achuthan et al. 2001). However, in prostate cancer, AR mutations are found in about $30 \%$ of the metastases that are resistant to hormone therapy (Navarro et al. 2002). In addition, the mutation rate is significantly increased in metastatic sites compared to primary tumors (Marcelli et al. 2000), especially after androgen-ablation therapy (Taplin et al. 1995). Many of the mutations are gain of function and are located in the ligand-binding domain, which results in inappropriate activation of AR by steroid hormones other than androgen and AR antagonists (Buchanan et al. 2001). For instance, several mutant $A R s$ such as Thr- $877 \rightarrow$ Ala, Leu-701 $\rightarrow$ His, and Leu-701 $\rightarrow$ His $/$ Thr-877 $\rightarrow$ Ala have a broadened spectrum of ligand responsiveness, and bicalutamide works as an agonist for these mutants (Hara et al. 2003). These mutations are considered to be responsible for the phenomenon 
of 'antiandrogen withdrawal syndrome' (Nelson et al. 2003).

\section{$E R / A R$ crosstalk with other growth factors}

During the progression from hormone-dependent to independent cancers, the crosstalk between ER/AR and other growth factor pathways is a complicated issue. There are several growth factors and their receptors involved in this process. The crosstalk between growth factor pathways and ER/AR occurs at multiple levels and is bidirectional with different importance in breast and prostate cancers. Novel therapies against these growth factors are emerging as alternative choices for the prevention and treatment of hormone-resistant breast cancer or prostate cancer.

Many of the estrogen-responsive genes code for peptide growth factors, membrane-bound tyrosine kinase receptors (TKRs), and several cellular signaling molecules, and usually their transcription is inversely correlated with ER expression (Schiff et al. 2004). On the contrary, the genotropic activity of ER is enhanced by several growth factor signaling pathways, including epidermal growth factor (EGF), insulin-like growth factor type I (IGF-1), and transforming growth factor$\alpha$ (TGF- $\alpha$ ), which enhance the phosphorylation of AF-1 on Ser-118 of ER by MAPK. This phosphorylation enhances the nuclear localization of coactivators and their interaction with nuclear ER, producing ligandindependent transcriptional activity of $\mathrm{AF}-1$, even in the presence of TAM, and is related to antihormone resistance (Kato et al. 1995, Schiff et al. 2003). Thus, increasing the expression of growth factors or upregulation of their receptors or the downstream signaling elements can promote antihormone-therapy resistance.

Membrane ERs can also function like growth factor receptors by binding to $\mathrm{p} 85$, a regulatory subunit of phosphoinositide 3-kinase (PI3K) at the cell membrane, leading to activation of the protein kinase Akt and the subsequent downstream signaling (Migliaccio et al. 2002). Therefore, membrane ER enhances the transcriptional activity of nuclear ER through a nongenotropic pathway. Both genotropic and nongenotropic actions seem to be complementary, even synergistic, not only for cellular growth but also for the emergence of hormone resistance in a low-estrogen environment (Schiff et al. 2003). In summary, ER may suppress the expression of other growth factor receptors and long-term estrogen suppression can reactivate the expression of membrane TKRs. This results in increased growth factor signaling, and ERK1/2 MAPK, and PI3K/Akt activities, alteration of ER subcellular localization and enhancement of the nongenotropic action, stimulating the malignant phenotype (Kumar et al. 2002, Schiff et al. 2004). More and more evidence suggests that the crosstalk between ER and these signaling pathways is upregulated or activated in endocrine-resistant breast cancers, and may be the major cause of endocrine resistance (Johnston et al. 2003). In an in vitro study, dual inhibition of MAPK with U-0126 and PI3K with Ly294002 have been found to decrease the sensitivity of ER to estradiol (Yue et al. 2003).

Among all the growth factors and growth factor receptors, the EGF receptor (EGFR) family seems to play a major role in promoting hormone refractory transition, in particular HER-2/neu is well known to associate with poorer prognostic phenotypes including high-grade histology, high proliferation rate, and ER negativity. There is also a tendency for HER-2/neuoverexpressed breast cancer to be less responsive to anti-estrogen therapies (Revillion et al. 1998). Introducing HER-2/neu cDNA into breast cancer cells promotes ligand-independent downregulation of ER, and converts cancer cells from estrogen-dependent to estrogen-independent (Pietras et al. 1995). Its signaling pathway can also disrupt the TAM-induced interaction of ER with the transcriptional corepressor N-CoR (Kurokawa et al. 2000, Kurokawa \& Arteaga 2001). High HER-2/neu expression constitutively activates PI3K/Akt. Active Akt renders MCF-7 cells from estrogen-dependent to -independent, and treating these cells with TAM actually stimulates instead of inhibiting their growth (Faridi et al. 2003). Since HER-2/neu overexpression is closely related with MAPK hyperactivity and TAM resistance, inhibiting MAPK can reverse TAM resistance in HER-2/neu-overexpressed breast cancer cells (Kurokawa et al. 2000).

The crosstalk between AR and growth factor signaling pathways of prostate cancer is very similar to that of breast cancer (Nelson et al. 2003). EGF, IGF-I, and keratinocyte growth factor all activate AR, especially IGF-I, and the AR antagonist casodex blocks this activation completely (Culig et al. 1994). This indicates that the activation is AR-dependent. Membrane-bound TKRs, especially HER-2/neu, were also observed to be involved in the progression to AIPC, as overexpression of HER-2/neu increases MAPK and Akt activities, phosphorylates AR, and then turns on downstream target genes in a ligandindependent manner (Lin et al. 2001).

The cytokine IL-6 is also related to the growth of breast and prostate cancers and the emergence of hormone resistance through its interaction with TKRs and intracellular signaling pathways. In both breast cancer and prostate cancer, elevated circulating levels 
of IL-6 are associated with worse prognosis, especially in AIPC (Drachenberg et al. 1999, Salgado et al. 2003). Serum IL-6 levels are significantly elevated in hormone-refractory prostate cancer patients as compared with earlier stages of the disease or with benign prostate hyperplasia (Drachenberg et al. 1999). In breast cancer, IL-6 increases intracellular aromatase activity (Honma et al. 2002). IL-6 also facilitates the formation of bone metastasis of both breast cancer and prostate cancer by stimulating osteoclasts (Roodman 2001). In prostate cancer, IL-6 is the most potent nonsteroidal regulator of AR activity. It alone causes the activation of AR to approximately $50 \%$ of the maximal activity induced by androgen (Culig 2003). IL-6 regulation of AR activity and prostate cancer growth occurs through MAPK and signal transducer and activator of transcription 3 (STAT3; Chen et al. 2000, Culig et al. 2002). It can also stimulate the autophosphorylation of HER-2/neu in prostate cancer cells and subsequently activate the downstream kinase signaling pathways (Qiu et al. 1998). Thus, IL-6 is important in mediating and enhancing the transition from hormone-dependent to hormone-independent of breast and prostate cancer cells.

Since long-term estrogen deprivation induces the expression of growth factors and growth factor receptors, and overexpressed growth factors and growth factor receptors facilitate the emergence of antihormone resistance, the question arises as to whether it is possible to not only treat antihormone-resistant cancer, but also to prevent the development of resistance by early treatment with anti-growth factor agents, either alone or in combination with anti-estrogen agents. Several experiments using such combinations have been reported, and have shown promising results (Schiff et al. 2004).

\section{Receptor-positive, receptor/ligand- independent (bypass pathway)}

The mechanisms involved in hormone-refractory transition are complicated. Several complementary or alternative pathways may occur simultaneously, some of which are capable of bypassing receptors completely. Inhibition of genotropic or nongenotropic pathways can lead to apoptosis in breast and prostate cancer cells. Blocking the apoptotic cascades by enhancing antiapoptotic genes, decreasing proapoptotic genes or through mutations in oncogenes or tumorsuppressor genes all are possible mechanisms for the bypass pathway.

The antiapoptotic gene $\mathrm{Bcl}-2$ is overexpressed in more than half of all human cancers. Overexpression of Bcl-2 occurs in $40-80 \%$ of human breast tumors (Nahta \& Esteva 2003) and also occurs frequently in prostate cancers. Overexpression of Bcl-2 is associated with the resistance to hormonal therapy and chemotherapy in both breast cancers and prostate cancers. This phenotype may come from the selection effect of antihormone agents. Treatment with Bcl-2 antisense in a prostate cancer animal model delays the emergence of androgen independence (Gleave et al. 1999). Transcriptional factor nuclear factor $\kappa \mathrm{B}(\mathrm{NF}-\kappa \mathrm{B})$ modulates the expression of genes involved in cell proliferation, differentiation, apoptosis, and metastasis. Constitutive activation of NF- $\kappa \mathrm{B}$ is noted in ER-negative breast cancer cells, in TAM-resistant MCF-7 cells (Gu et al. 2002), and during breast cancer progression to hormone-independent growth (Nakshatri et al. 1997).

Mutation or decreased expression of tumorsuppressor genes is also an alternative pathway. Tumor-suppressor genes are involved in the DNArepair process to maintain genomic integrity, cell-cycle control, and induction of apoptosis in damaged cells and regulation of transcription. Failure of tumorsuppressor genes increases the probability of accumulation of replication errors and genomic instability, making cells less responsive to apoptotic signals, and contributing to an increase in hormone-independence and tumor aggressiveness. The most common mutated tumor-suppressor gene is p53 (Levine et al. 1991). In hormone-refractory prostate cancers p53 was positively increased during hormonal therapy from $17 \%$ of untreated primary tumors to $40 \%$ of hormonerefractory recurrences. The percentage of mutations was significantly higher in cases of AR gene amplification (Koivisto \& Rantala 1999). PTEN (phosphatase and tensin homologue deleted on chromosome 10) is another tumor-suppressor gene that has been noted to be mutated in both breast cancer and prostate cancer (Li et al. 1997). In breast cancer, BRCA1 and BRCA2 mutations are well known for hereditary and sporadic breast cancers (Wooster \& Weber 2003). Recently these two genes were found to be related to prostate cancer development (Rosen et al. 2001).

\section{Receptor-negative, hormone-independent}

Since ER/AR are responsible for the ligand-induced signal transduction, ER/AR are also the main targets of antihormone agents. With decreased expression of ER/AR these therapeutic agents lose their targets, which may be a cause of resistance. In fact, absence of ER expression is the most common mechanism of de novo resistance in breast cancers, whereas a complete loss of 
ER expression is not common in acquired resistance (Clarke et al. 2003). Decreased expression of receptors usually comes from hypermethylation of the responsible genes. DNA hypermethylation of the AR promoter region leading to AR downregulation has been identified in $30 \%$ of hormone-refractory prostate cancers, compared with only $10 \%$ in untreated primary tumors (Suzuki et al. 2003). Reverse DNA hypermethylation by cytosine DNA methyltransferase inhibitors restores androgen responsiveness in androgenrefractory prostate cancer cells, making them sensitive to growth inhibition by antiandrogen agents (Izbicka et al. 1999). Hypermethylation of a $\mathrm{CpG}$ island in the $5^{\prime}$ region of the ER gene is seen in ER-negative breast cancer cells; demethylation of this site reactivates ER gene expression (Ferguson et al. 1995). The same condition has also been reported in AR-negative prostate cancer cells (Jarrard et al. 1998).

\section{Novel agents targeting sex hormone receptors in hormone-resistant breast and prostate cancers}

In recent years, there has been growing interest in the development of nonsteroidal modulators for steroid hormone receptors as therapeutic agents. SERMs, SARMs, and nonsteroidal modulators for progesterone receptor have been successfully developed (Zhi et al. 1998, 2000, Hamann et al. 1999, Mitlak \& Cohen 1999, Weryha et al. 1999). These modulators are well characterized for their better receptor specificity and selectivity than steroidal ligands, and are more flexible in structural modification for pharmacologic properties. More importantly, with these nonsteroidal chemicals, it may achieve tissue-selective actions and thus generate compounds with diverse purpose suitable for specific therapeutic needs.

\section{SERMs}

Estrogens are widely used clinically to control reproduction and for hormone therapy and the treatment of menopausal symptoms in women. Although beneficial in these contexts, estrogen use has also been implicated as a risk factor in breast and uterine cancer, particularly since the first published report from the Women's Health Initiative (Rossouw et al. 2002), suggesting that a greater measure of flexibility to control unwanted side effects would be desirable. Consequently, the recognition of SERMs as agents able to elicit estrogenic effects in a tissue-specific manner has expanded the potential population that could benefit from ER ligand therapies. The prototypic
SERM is the trans isomer of TAM (Gottardis \& Jordan 1987, Gottardis et al. 1988). Although it was first proposed to use for regulating fertility, it has been applied primarily as a drug to treat breast cancer (Harper \& Walpole 1967, Williamson \& Ellis 1973). The ability of TAM to inhibit ER action has long been considered integral to its utility in the breast cancer arena, and this is consistent with numerous studies and clinical trials demonstrating an effect of TAM in ER-positive cells or breast tumors and an absence of any significant activity in those lacking ER expression (Early Breast Cancer Trialists' Collaborative Group 1998). The subsequent observation of the estrogen-like effects of TAM in the human skeleton (Love et al. 1992) was important to the conceptualization of SERMs as potential drugs for indications other than breast cancer. The success of TAM as a SERM has been a driving force in the search for new SERMs as well as selective modulators for other nuclear/steroid receptors. Raloxifene, like TAM, exhibits anti-estrogen activity in the breast and estrogen activity in the skeleton. However, raloxifene lacks the significant uterotropic activity associated with TAM and therefore represents an improved agonist/antagonist profile (Delmas et al. 1997, Ettinger et al. 1999). In addition, a number of other compounds, including lasofoxifene, arzoxifene, and bazedoxifene, are under development, which may one day be of clinical use for chemoprevention of breast cancer or treatment and prevention of osteoporosis (Baracat et al. 1999, Suh et al. 2001). Consequently, the recognition of SERMs as agents able to elicit estrogenic effects in a tissue-specific manner has expanded the potential population that could benefit from ER ligand therapies.

\section{SARMs}

Chemicals that regulate the transcriptional activity of AR can be further categorized into structural (steroidal and nonsteroidal) and functional (androgenic and antiandrogenic) classes. Steroidal androgens, mainly testosterone and its derivatives, have been used clinically as replacement therapies for androgen deficiency (Bagatell \& Bremner 1996). Antiandrogens are used to counteract the undesirable actions of excessive androgens (e.g. to treat acne, hirsutism, male-pattern baldness, and androgen-dependent prostate cancer; Neumann 1982, McLeod et al. 1993). Nonsteroidal antiandrogens, such as FLU (Eulexin), nilutamide (Anandron), and bicalutamide (Casodex), bind to the AR LBD and, therefore, are devoid of antigonadotropic, anti-estrogenic, and progestational effects. These agents are advantageous over 
steroidal antiandrogens (e.g. megestrol acetate, cyproterone acetate) in terms of specificity and selectivity (Cockshott et al. 1990, Teutsch et al. 1994). Whereas steroidal antiandrogens have been used clinically for a long period of time, nonsteroidal androgens were not conceptualized until very recently. Although androgen therapies are currently available, they are based primarily on delivery of testosterone or its derivatives by injections or skin patches (Negro-Vilar 1999). Neither approach is optimal because injections result in undesirable fluctuations in serum testosterone levels, and skin patches are associated with irritation and rashes. Oral preparations of currently available androgens are not recommended because of their relatively low efficacy, fluid retention, liver toxicity, prostatic hypertrophy, and gynecomastia. Therefore, the goal of preservation of positive androgen effects in some tissues, while minimizing negative side effects in other tissues, has stimulated a search for SARMs. Recently, a group of nonsteroidal androgens that are electrophilic derivatives of bicalutamide and hydroxyflutamide was discovered (Dalton et al. 1998). Also, several analogs of quinoline-based AR antagonists, notably tricyclic pyridinodihydroquinoline derivatives, showed promising anabolic effects without any significant action on the prostate and seminal vesicles (Edwards et al. 1999, Hamann et al. 1999, Higuchi et al. 1999, Zhi et al. 1999). The selective action of these compounds on muscle and bone tissues implies important clinical applications for these androgen analogs in the treatment of elderly men and patients with wasting diseases. These studies marked the emergence of a novel category of pharmacological agents with potential applications in androgen therapy. Assessments of the in vivo SARM activity of these compounds are underway in animals as well as in humans, and they show a promising tissue-selective activity profile. Animal experiments with one such SARM, LGD2226, revealed that it prevented loss of bone mineral density associated with orchidectomy in rats; in contrast, LGD2226 did not stimulate prostate weights above those observed for intact rats (NegroVilar 1999). The discovery of nonsteroidal androgens provides an opportunity to identify agents with superior pharmacokinetic profiles to steroidal androgens and implicates the possibility to obtain tissue-selective AR modulators.

\section{Fulvestrant}

To overcome crosstalk between ER and other growth factors, several novel agents have been evaluated, some of which are currently in clinical practice. The most straightforward method is to diminish functional ER. Fulvestrant (Faslodex; ICI 182,780), is a pure anti-ER agent which competes with estrogen for binding to ER, with much higher affinity ( 89 versus $2.5 \%$ binding affinity of estrodiol; Wakeling et al. 1991, Morris \& Wakeling 2002). Fulvestrant reduces the rate of ER dimerization, increases ER degradation (Fawell et al. 1990), and reduces ER shuttling from the membrane to the nucleus by blocking its nuclear uptake (Dauvois et al. 1993). The loss of ER not only abrogates the transcriptional effect of estrogen, but also blocks the activation of ER by other growth factors. More importantly fulvestrant blocks the agonistic effects of both estrogen and TAM without a demonstrable estrogen-agonistic effect (Wakeling \& Bowler 1988, Howell 2001). A single dose of fulvestrant has been shown to decrease ER, PR, and Ki-67 levels significantly in the primary breast cancers of postmenopausal women compared to TAM (Robertson et al. 2001). For the treatment of postmenopausal women with receptor-positive breast cancers, fulvestrant was at least as effective as aromatase inhibitors and TAM (Howell et al. 2002, 2004, Osborne et al. 2002). The long-term efficacy and side effects of fulvestrant still need to be followed.

\section{Hsp90 inhibitors}

As a chaperone protein, Hsp90 binds to over 100 kinds of proteins that are involved in multiple signaling pathways utilized by cancer cells for growth and survival. These proteins include steroid hormone receptors (ER, AR, PR), growth factor receptors (EGFR, HER-2), several kinases (Akt, c-RAF-1), transcriptional factors, and mutated or chimeric signaling proteins (mutated p53, p210 ${ }^{\mathrm{Bcr}-\mathrm{Abl}}$; Isaacs et al. 2003). Hsp90 serves as an important regulator to control the folding, intracellular disposition, and proteolytic turnover of many key regulatory proteins of cell growth, differentiation, and survival. It is constitutively expressed at 2-10-fold higher levels in tumor cells compared to normal cells (Isaacs et al. 2003), its protective effect allows tumor cells to tolerate the mutation of multiple critical signaling molecules that would otherwise be lethal. Therefore it may be important for cancer cell development and survival (Bagatell \& Whitesell 2004). Hsp90 inhibitors including geldanamycin, the derivative product of geldanamycin -17-allylaminogeldanamycin (17-AAG), help to degrade several oncogenic proteins, and block several oncogenic pathways (Workman 2004). More surprisingly, the Hsp90 that is derived from tumor cells has a 100-fold-higher binding affinity for 17-AAG than 
the Hsp90 from normal cells (Kamal et al. 2003). This information suggests that Hsp90 is a good target of 17-AAG for treating cancers. In breast cancer and prostate cancer, Hsp90 inhibitors can effectively downregulate ER and AR protein levels (Segnitz \& Gehring 1997, Bagatell et al. 2001). Hsp90 inhibitors downregulate HER-2/neu, inhibit Akt activation, and enhance paclitaxel-induced apoptosis in HER-2/neuoverexpressed breast cancer cells (Basso et al. 2002, Solit et al. 2003). Thus Hsp90 inhibitors can be used to target hormone-dependent and -independent breast and prostate cancers with high activities of growth factor signaling pathways. A clinical trial combining 17-AAG and paclitaxel together against HER-2/neuoverexpressed breast cancer and prostate cancer is currently ongoing.

\section{Novel agents targeting tyrosine kinase receptor in hormone-resistant breast and prostate cancers}

Since crosstalks with other growth factors and their receptors - especially tyrosine kinase receptors - are important mechanisms for the emergence of antihormone resistance, an alternative method to block or reverse this resistance is targeting the growth factors and receptors themselves. Tyrosine kinases are tightly regulated enzymes that play an important role in the control of most fundamental cellular processes, including cell proliferation, differentiation, metabolism, migration, and survival. There are several potentially effective interventions of the signaling pathways of tyrosine kinase receptors, including agents targeting growth factors; anti-growth factor receptor antibodies such as trastuzumab (Herceptin), which target HER-2/ neu-overexpressed breast cancer, and pertuzumab (2C4), which binds to a different epitope of HER-2/neu ectodomain than trastuzumab; monoclonal antibodies against EGFR such as IMC-C225 and a fully humanized anti-EGFR monoclonal antibody ABXEGF; low-molecular-mass EGFR-specific tyrosine kinase inhibitors, such as gefitinib (ZD1839 or Iressa), which works by competing at the ATP-binding site on the tyrosine kinase domain of EGFR; OSI-774 (Tarceva), which specifically blocks the kinase activity of EGFR and EGFR autophosphorylation; CI-1033, which acts as a pan-EGFR tyrosine kinase inhibitor, and PKI-166, which is a reversible tyrosine kinase inhibitor and can block the enzymatic activity of HER$2 / n e u$. All of these agents are presently in clinical trials or clinical practices and have been reviewed extensively (Johnston et al. 2003, Normanno et al. 2003, Madhusudan \& Ganesan 2004). Thus, we will not discuss these agents here. Instead, we will describe a couple of novel agents that may have potential to interfere tyrosine kinase receptors.

\section{Emodin}

Emodin (3 methyl-1,6,8-trihydroxyanthraquinone), isolated from Polygonum uspidatum, is an inhibitor of protein tyrosine kinases (Jayasuriya et al. 1992). Emodin also initiates apoptotic pathways in cancer cells, such as hepatoma (Jing et al. 2002), cervical cancer (Srinivas et al. 2003), and leukemia cells (Chen et al. 2002). Emodin suppresses the autophosphorylation and transphosphorylation activities of HER-2/neu tyrosine kinase, resulting in tyrosine hypophosphorylation of p185neu in HER-2/neu-overexpressing breast cancer cells and non-small cell lung cancer (Zhang et al. 1995, Zhang \& Hung 1996), suppressing their growth and sensitizing these tumors to several chemotherapeutic agents including paclitaxel, doxorubicin, etoposide, and cisplatin. In vivo Emodin also represses the growth of HER-2/neu-overexpressed breast cancer cells and sensitizes these cells to paclitaxel (Zhang et al. 1999). Since emodin inhibits tyrosine kinase activity, suppresses HER-2/neu phosphorylation, and enhances chemosensitivity of breast cancers, it has the potential to be an alternative therapy for HER-2/neuoverexpressed, hormone-resistant breast cancers.

\section{Type 5 adenovirus early region $1 \mathrm{~A}(\mathrm{E} 1 \mathrm{~A})$ protein}

The E1A of human adenovirus type 5 encodes the proteins that activate viral transcription, thus permitting viral replication in infected cells (Flint \& Shenk 1989). E1A was reported to have an antitumor growth effect and anti-metastasis effect (Pozzatti et al. 1988a,b, Frisch 1991, Chinnadurai 1992, Frisch \& Mymryk 2002). E1A can downregulate HER-2/neu expression in human tumor cells, and inhibits the growth of HER-2/ neu-overexpressed cancer cells in vitro and in vivo (Yu et al. 1990, 1991, 1993). There are several molecular mechanisms that may contribute to this anti-cancer effect of E1A: E1A can suppress HER-2/neu gene expression; E1A inhibits activation of NF- $\kappa \mathrm{B}$ through suppression of I $\mathrm{K} B$ kinase (IKK) activity and $\mathrm{I} \kappa \mathrm{B}$ phosphorylation, rendering cells to be more sensitive to environmental stress (Shao et al. 1997, 1999, 2001); E1A also negatively regulates the expression of Axl, which is a transforming receptor tyrosine kinase essential for tumor cell growth (Lee et al. 1999). When combined with chemotherapeutic agents, E1A can sensitize cells to the cytotoxic effect of drugs (Lowe et al. 1993, Ueno et al. 1997). This sensitizing effect, 
which can be observed in a preclinical gene therapy setting using an orthotopic breast cancer animal model, may, through E1A, activate $\mathrm{p} 38$ and inactivate Akt (Liao \& Hung 2003, Liao et al. 2004).

The first clinical trial of E1A gene therapy was initiated in 1996, which was the first gene-therapy trial focused on breast cancers and ovarian cancers (Hortobagyi et al. 2001). In this trial, E1A was delivered by a specific liposome into the thoracic cavity of breast cancer patients with pleural effusion, or into the peritoneal cavity of ovarian cancer patients with ascites. After E1A treatment, HER-2/neu expression in cancer cells derived from patients with HER-2/neuoverexpressing cancers decreased significantly. In addition, the local concentration of TNF $\alpha$ increased. E1A was known to sensitize TNF $\alpha$-induced apoptosis; thus the enhanced TNF $\alpha$ may help E1A-mediated anti-cancer activity (Wold 1993, Shao et al. 1999). There are other clinical trials focused on breast, ovarian, and head and neck cancer that have been reported indicating the feasibility of the E1A gene therapy (Yoo et al. 2001, Villaret et al. 2002, Madhusudan et al. 2004).

In summary, E1A as a therapeutic gene can be used in several kinds of cancer. Its function is through not only downregulating HER-2/neu expression, but also interfering with mitogenic signaling pathways. These effects may work on hormone-dependent or -independent breast cancers, and may reverse hormone resistance.

\section{Conclusion}

The endocrine system controls the long-term coordination of whole body organs. A dysregulated response to hormones, in some cases, leads organs to receive the hormone as a growth stimulant and results in malignancy. Breast cancer and prostate cancer are the most well-known and well-studied examples of this. Although in most cases the cancers are initially sex-hormone-positive and responsive to antihormone therapy, the complicated interactions in these cells eventually will make the resistance inevitable. From previous reviews we know the emergence of resistance is composed of several mechanisms, which can work alone or in cooperation with each other, making treatment more complicated and difficult. However, the more we know about the mechanisms, the better we can predict the prognosis of patients and, more importantly, prevent the emergence of resistance and treat patients with different phenotypes.

One such example is the aromatase inhibitors. In postmenopausal women, aromatase can inhibit the production of estrogen from different sources, without the stimulatory effect from ligand, and aromatase inhibitors can prevent the emergence of resistance more effectively than TAM, as shown in several clinical trials including primary tumors, metastatic tumors, and chemoprevention trials (Fricker 2004). Following aromatase inhibitors, the pure anti-estrogen agent, fulvestrant, was shown to be more effective than aromatase inhibitors in postmenopausal women (Coleman 2003).

Cancer cells are heterogenous. There are differences not only between different individuals but also between different cells in the same individual. Currently there are emerging new tests to examine the phenotypes of cancers before we start to treat them or before we change the treatment protocols. Additionally, the therapeutic methods can be single or combination methodologies. In treating hormone-dependent cancers, there are also several preclinical and clinical trials combining antihormone agents with anti-growth factor agents to block crosstalk, therefore preventing and overcoming antihormone resistance. It is optimistic that combination therapies may soon provide effective strategies for the treatment of breast cancers and prostate cancers, and prevent the emergence of resistance.

\section{Acknowledgements}

The authors declare that there is no conflict of interest that would prejudice the impartiality of this scientific work.

\section{References}

Aarnisalo P, Palvimo JJ \& Janne OA 1998 CREB-binding protein in androgen receptor-mediated signaling PNAS 95 2122-2127.

Achuthan R, Bell SM, Roberts P, Leek JP, Horgan K, Markham AF, MacLennan KA \& Speirs V 2001 Genetic events during the transformation of a tamoxifensensitive human breast cancer cell line into a drugresistant clone. Cancer Genetics and Cytogenetics 130 166-172.

Anzick SL, Kononen J, Walker RL, Azorsa DO, Tanner MM, Guan XY, Sauter G, Kallioniemi OP, Trent JM \& Meltzer PS 1997 AIB1, a steroid receptor coactivator amplified in breast and ovarian cancer. Science 277 965-968.

Bagatell CJ \& Bremner WJ 1996 Androgens in men - uses and abuses. New England Journal of Medicine 334 707-714.

Bagatell R \& Whitesell L 2004 Altered Hsp90 function in cancer: a unique therapeutic opportunity. Molecular Cancer Therapeutics 3 1021-1030.

Bagatell R, Khan O, Paine-Murrieta G, Taylor CW, Akinaga S \& Whitesell L 2001 Destabilization of steroid receptors 
by heat shock protein 90-binding drugs: a ligandindependent approach to hormonal therapy of breast cancer. Clinical Cancer Research 7 2076-2084.

Bakin RE, Gioeli D, Sikes RA, Bissonette EA \& Weber MJ 2003 Constitutive activation of the Ras/mitogen-activated protein kinase signaling pathway promotes androgen hypersensitivity in LNCaP prostate cancer cells. Cancer Research 63 1981-1989.

Baracat E, Haidar M, Lopez FJ, Pickar J, Dey M \& NegroVilar A 1999 Estrogen activity and novel tissue selectivity of delta8,9-dehydroestrone sulfate in postmenopausal women. Journal of Clinical Endocrinology and Metabolism 84 2020-2027.

Basso AD, Solit DB, Munster PN \& Rosen N 2002

Ansamycin antibiotics inhibit Akt activation and cyclin D expression in breast cancer cells that overexpress HER2. Oncogene 21 1159-1166.

Bautista S, Valles H, Walker RL, Anzick S, Zeillinger R, Meltzer P \& Theillet C 1998 In breast cancer, amplification of the steroid receptor coactivator gene AIB1 is correlated with estrogen and progesterone receptor positivity. Clinical Cancer Research 4 2925-2929.

Berrevoets CA, Doesburg P, Steketee K, Trapman J \& Brinkmann AO 1998 Functional interactions of the AF-2 activation domain core region of the human androgen receptor with the amino-terminal domain and with the transcriptional coactivator TIF2 transcriptional intermediary factor2. Molecular Endocrinology 12 1172-1183.

Berstein LM, Zheng H, Yue W, Wang JP, Lykkesfeldt AE, Naftolin F, Harada H, Shanabrough M \& Santen RJ 2003 New approaches to the understanding of tamoxifen action and resistance. Endocrine-Related Cancer 10 267-277.

Berstein LM, Wang JP, Zheng H, Yue W, Conaway M \& Santen RJ 2004 Long-term exposure to tamoxifen induces hypersensitivity to estradiol. Clinical Cancer Research $\mathbf{1 0}$ 1530-1534.

Bevan CL, Hoare S, Claessens F, Heery DM \& Parker MG 1999 The AF1 and AF2 domains of the androgen receptor interact with distinct regions of SRC1. Molecular and Cellular Biology 19 8383-8392.

Brady ME, Ozanne DM, Gaughan L, Waite I, Cook S, Neal DE \& Robson CN 1999 Tip60 is a nuclear hormone receptor coactivator. Journal of Biological Chemistry 274 17599-17604.

Brogden RN \& Chrisp P 1991 Flutamide. A review of its pharmacodynamic and pharmacokinetic properties \& therapeutic use in advanced prostatic cancer. Drugs Aging 1 104-115.

Buchanan G, Greenberg NM, Scher HI, Harris JM, Marshall VR \& Tilley WD 2001 Collocation of androgen receptor gene mutations in prostate cancer. Clinical Cancer Research 7 1273-1281.

Castro-Rivera E, Samudio I \& Safe S 2001 Estrogen regulation of cyclin D1 gene expression in ZR-75 breast cancer cells involves multiple enhancer elements. Journal of Biological Chemistry 276 30853-30861.
Chakravarti D, LaMorte VJ, Nelson MC, Nakajima T, Schulman IG, Juguilon, H, Montminy, M \& Evans RM 1996 Role of CBP/p300 in nuclear receptor signaling. Nature 383 99-103.

Chen H, Lin RJ, Schiltz RL, Chakravarti D, Nash A, Nagy L, Privalsky ML, Nakatani Y \& Evans RM 1997 Nuclear receptor coactivator ACTR is a novel histone acetyltransferase and forms a multimeric activation complex with $\mathrm{P} / \mathrm{CAF}$ and $\mathrm{CBP} / \mathrm{p} 300$. Cell 90 569-580.

Chen T, Wang LH \& Farrar WL 2000 Interleukin 6 activates androgen receptor-mediated gene expression through a signal transducer and activator of transcription 3-dependent pathway in LNCaP prostate cancer cells. Cancer Research 60 2132-2135.

Chen YC, Shen SC, Lee WR, Hsu FL, Lin HY, Ko CH \& Tseng SW 2002 Emodin induces apoptosis in human promyeloleukemic HL-60 cells accompanied by activation of caspase 3 cascade but independent of reactive oxygen species production. Biochemical Pharmacology 64 1713-1724.

Chinnadurai G 1992 Adenovirus Ela as a tumor-suppressor gene. Oncogene 7 1255-1258.

Clarke R, Liu MC, Bouker KB, Gu Z, Lee RY, Zhu Y, Skaar TC, Gomez B, O'Brien K, Wang Y \& Hilakivi-Clarke LA 2003 Antiestrogen resistance in breast cancer and the role of estrogen receptor signaling. Oncogene 22 7316-7339.

Cockshott ID, Cooper KJ, Sweetmore DS, Blacklock NJ \& Denis L 1990 The pharmacokinetics of Casodex in prostate cancer patients after single and during multiple dosing. European Urology 18 (Suppl 3) 10-17.

Coleman RE 2003 Current and future status of adjuvant therapy for breast cancer. Cancer 97 880-886.

Culig Z 2003 Role of the androgen receptor axis in prostate cancer. Urology 62 21-26.

Culig Z, Hobisch A, Cronauer MV, Radmayr C, Trapman J, Hittmair A, Bartsch G \& Klocker H 1994 Androgen receptor activation in prostatic tumor cell lines by insulinlike growth factor-I, keratinocyte growth factor \& epidermal growth factor. Cancer Research 54 5474-5478.

Culig Z, Bartsch G \& Hobisch A 2002 Interleukin-6 regulates androgen receptor activity and prostate cancer cell growth. Molecular and Cellular Endocrinology 197 231-238.

Dalton JT, Mukherjee A, Zhu Z, Kirkovsky L \& Miller DD 1998 Discovery of nonsteroidal androgens. Biochemical and Biophysical Research Communications 244 1-4.

Dauvois S, White R \& Parker MG 1993 The antiestrogen ICI 182780 disrupts estrogen receptor nucleocytoplasmic shuttling. Journal of Cell Science 106 1377-1388.

Delmas PD, Bjarnason NH, Mitlak BH, Ravoux AC, Shah AS, Huster WJ, Draper M \& Christiansen C 1997 Effects of raloxifene on bone mineral density, serum cholesterol concentrations \& uterine endometrium in postmenopausal women. New England Journal of Medicine 337 1641-1647.

Dotzlaw H, Leygue E, Watson PH \& Murphy LC 1999 Estrogen receptor-beta messenger RNA expression in human breast tumor biopsies: relationship to steroid 
receptor status and regulation by progestins. Cancer Research 59 529-532.

Drachenberg DE, Elgamal AA, Rowbotham R, Peterson M \& Murphy GP 1999 Circulating levels of interleukin-6 in patients with hormone refractory prostate cancer. Prostate 41 127-133.

Early Breast Cancer Trialists' Collaborative Group 1998 Tamoxifen for early breast cancer: an overview of the randomised trials. Lancet 351 1451-1467.

Edwards JP, Higuchi RI, Winn DT, Pooley CL, Caferro TR, Hamann LG, Zhi L, Marschke KB, Goldman ME \& Jones TK 1999 Nonsteroidal androgen receptor agonists based on 4-trifluoromethyl-2H-pyrano[3,2-g]quinolin-2one. Bioorganic \& Medicinal Chemistry Letters 9 1003-1008.

Ettinger B, Black DM, Mitlak BH, Knickerbocker RK, Nickelsen T, Genant HK, Christiansen C, Delmas PD, Zanchetta JR, Stakkestad J, et al. 1999 Reduction of vertebral fracture risk in postmenopausal women with osteoporosis treated with raloxifene: results from a 3-year randomized clinical trial. Multiple Outcomes of Raloxifene Evaluation (MORE) Investigators. Journal of the American Medical Association 282 637-645.

Fan S, Ma YX, Wang C, Yuan RQ, Meng Q, Wang JA, Erdos M, Goldberg ID, Webb P, Kushner PJ, et al. 2001 Role of direct interaction in BRCA1 inhibition of estrogen receptor activity. Oncogene 20 77-87.

Faridi J, Wang L, Endemann G \& Roth RA 2003 Expression of constitutively active Akt-3 in MCF-7 breast cancer cells reverses the estrogen and tamoxifen responsivity of these cells in vivo. Clinical Cancer Research 9 2933-2939.

Fawell SE, White R, Hoare S, Sydenham M, Page M \& Parker MG 1990 Inhibition of estrogen receptor-DNA binding by the "pure" antiestrogen ICI164,384 appears to be mediated by impaired receptor dimerization. PNAS 87 6883-6887.

Feldman BJ \& Feldman D 2001 The development of androgen-independent prostate cancer. Nature Reviews Cancer 1 34-45.

Ferguson AT, Lapidus RG, Baylin SB \& Davidson NE 1995 Demethylation of the estrogen receptor gene in estrogen receptor-negative breast cancer cells can reactivate estrogen receptor gene expression. Cancer Research $\mathbf{5 5}$ 2279-2283.

Fisher B, Costantino JP, Wickerham DL, Redmond CK, Kavanah M, Cronin WM, Vogel V, Robidoux A, Dimitrov N, Atkins J, et al. 1998 Tamoxifen for prevention of breast cancer: report of the National Surgical Adjuvant Breast and Bowel Project P-1 Study. Journal of the National Cancer Institute 90 1371-1388.

Flint J \& Shenk T 1989 Adenovirus E1A protein paradigm viral transactivator. Annual Review of Genetics $\mathbf{2 3}$ 141-161.

Fricker J 2004 End of the road for tamoxifen? Lancet Oncology 52.

Frisch SM 1991 Antioncogenic effect of adenovirus E1A in human tumor cells. PNAS 88 9077-9081.
Frisch SM \& Mymryk JS 2002 Adenovirus-5 E1A: paradox and paradigm. Nature Reviews Molecular Cell Biology 3 441-452.

Fu M, Wang C, Zhang X \& Pestell R 2003 Nuclear receptor modifications and endocrine cell proliferation. Journal of Steroid Biochemistry and Molecular Biology 85 133-138.

Fujimoto N, Mizokami A, Harada S \& Matsumoto T 2001 Different expression of androgen receptor coactivators in human prostate. Urology 58 289-294.

Fuqua SA, Wiltschke C, Zhang QX, Borg A, Castles CG, Friedrichs WE, Hopp T, Hilsenbeck S, Mohsin S, O'Connell P \& Allred DC 2000 A hypersensitive estrogen receptor-alpha mutation in premalignant breast lesions. Cancer Research 60 4026-4029.

Fuqua SA, Schiff R, Parra I, Moore JT, Mohsin SK, Osborne CK, Clark GM \& Allred DC 2003 Estrogen receptor beta protein in human breast cancer: correlation with clinical tumor parameters. Cancer Research 63 2434-2439.

Gleave M, Tolcher A, Miyake H, Nelson C, Brown B, Beraldi E \& Goldie J 1999 Progression to androgen independence is delayed by adjuvant treatment with antisense Bcl-2 oligodeoxynucleotides after castration in the LNCaP prostate tumor model. Clinical Cancer Research 5 2891-2898.

Goss PE \& Strasser K 2002 Tamoxifen resistant and refractory breast cancer: the value of aromatase inhibitors. Drugs 62 957-966.

Gottardis MM \& Jordan VC 1987 Antitumor actions of keoxifene and tamoxifen in the $\mathrm{N}$-nitrosomethylureainduced rat mammary carcinoma model. Cancer Research 47 4020-4024.

Gottardis MM, Robinson SP, Satyaswaroop PG \& Jordan VC 1988 Contrasting actions of tamoxifen on endometrial and breast tumor growth in the athymic mouse. Cancer Research 48 812-815.

Gregory CW, He B, Johnson RT, Ford OH, Mohler JL, French FS \& Wilson EM 2001 a A mechanism for androgen receptor-mediated prostate cancer recurrence after androgen deprivation therapy. Cancer Research 61 4315-4319.

Gregory CW, Johnson RT Jr, Mohler JL, French FS \& Wilson EM $2001 b$ Androgen receptor stabilization in recurrent prostate cancer is associated with hypersensitivity to low androgen. Cancer Research $\mathbf{6 1}$ 2892-2898.

Gu Z, Lee RY, Skaar TC, Bouker KB, Welch JN, Lu J, Liu A, Zhu Y, Davis N, Leonessa F, et al. 2002 Association of interferon regulatory factor-1, nucleophosmin, nuclear factor-kappaB \& cyclic AMP response element binding with acquired resistance to Faslodex ICI182,780. Cancer Research 62 3428-3437.

Hall JM \& McDonnell DP 1999 The estrogen receptor betaisoform ERbeta of the human estrogen receptor modulates ERalpha transcriptional activity and is a key regulator of the cellular response to estrogens and antiestrogens. Endocrinology 140 5566-5578. 
Hamann LG, Mani NS, Davis RL, Wang XN, Marschke KB \& Jones TK 1999 Discovery of a potent, orally active, nonsteroidal androgen receptor agonist: 4-ethyl-1,2,3,4tetrahydro-6- trifluoromethyl -8-pyridono[5,6-g]quinoline LG121071. Journal of Medicinal Chemistry 42 210-212.

Hara T, Miyazaki J, Araki H, Yamaoka M, Kanzaki N, Kusaka M \& Miyamoto M 2003 Novel mutations of androgen receptor: a possible mechanism of bicalutamide withdrawal syndrome. Cancer Research 63 149-153.

Harada N, Utsumi T \& Takagi Y 1993 Tissue-specific expression of the human aromatase cytochrome P-450 gene by alternative use of multiple exons 1 and promoters $\&$ switching of tissue-specific exons 1 in carcinogenesis. PNAS 90 11312-11316.

Harper MJ \& Walpole AL 1967 A new derivative of triphenylethylene: effect on implantation and mode of action in rats. Journal of Reproduction and Fertility 13 101-119.

He B, Kemppainen JA, Voegel JJ, Gronemeyer H \& Wilson EM 1999 Activation function 2 in the human androgen receptor ligand binding domain mediates interdomain communication with the NH 2 -terminal domain. Journal of Biological Chemistry 274 37219-37225.

Heinlein CA, Ting HJ, Yeh S \& Chang C 1999 Identification of ARA70 as a ligand-enhanced coactivator for the peroxisome proliferator-activated receptor gamma. Journal of Biological Chemistry 274 16147-16152.

Higuchi RI, Edwards JP, Caferro TR, Ringgenberg JD, Kong JW, Hamann LG, Arienti KL, Marschke KB, Davis RL, Farmer LJ \& Jones TK 1999 4-Alkyl-and 3,4-dialkyl-1,2,3,4 tetrahydro-8-pyridono[5,6g]quinolines: potent, nonsteroidal androgen receptor agonists. Bioorganic \& Medicinal Chemistry Letters 9 1335-1340.

Hong H, Kohli K, Garabedian MJ \& Stallcup MR 1997 GRIP1, a transcriptional coactivator for the AF-2 transactivation domain of steroid, thyroid, retinoid \& vitamin D receptors. Molecular and Cellular Biology 17 2735-2744.

Honma S, Shimodaira K, Shimizu Y, Tsuchiya N, Saito H, Yanaihara T \& Okai T 2002 The influence of inflammatory cytokines on estrogen production and cell proliferation in human breast cancer cells. Endocrine Journal 49 371-377.

Hortobagyi GN, Ueno NT, Xia W, Zhang S, Wolf JK, Putnam JB, Weiden PL, Willey JS, Carey M, Branham DL, et al. 2001 Cationic liposome-mediated E1A gene transfer to human breast and ovarian cancer cells and its biologic effects: a phase I clinical trial. Journal of Clinical Oncology 19 3422-3433.

Howell A 2001 Preliminary experience with pure antiestrogens. Clinical Cancer Research 7 4369s-4375s; discussion 4411s-4412s.

Howell A, Robertson JF, Quaresma Albano J, Aschermannova A, Mauriac L, Kleeberg UR, Vergote I, Erikstein B, Webster A \& Morris C 2002 Fulvestrant, formerly ICI 182,780, is as effective as anastrozole in postmenopausal women with advanced breast cancer progressing after prior endocrine treatment. Journal of Clinical Oncology 20 3396-3403.

Howell A, Robertson JF, Abram P, Lichinitser MR, Elledge R, Bajetta E, Watanabe T, Morris C, Webster A, Dimery I \& Osborne CK 2004 Comparison of fulvestrant versus tamoxifen for the treatment of advanced breast cancer in postmenopausal women previously untreated with endocrine therapy: a multinational, double-blind, randomized trial. Journal of Clinical Oncology 22 1605-1613.

Huang SM \& Stallcup MR 2000 Mouse Zac1, a transcriptional coactivator and repressor for nuclear receptors. Molecular and Cellular Biology 20 1855-1867.

Huang N, vom Baur E, Garnier JM, Lerouge T, Vonesch JL, Lutz Y, Chambon P \& Losson R 1998 Two distinct nuclear receptor interaction domains in NSD1, a novel SET protein that exhibits characteristics of both corepressors and coactivators. EMBO Journal 17 3398-3412.

Ikonen T, Palvimo JJ \& Janne OA 1997 Interaction between the amino-and carboxyl-terminal regions of the rat androgen receptor modulates transcriptional activity and is influenced by nuclear receptor coactivators. Journal of Biological Chemistry 272 29821-29828.

Isaacs JS, Xu W \& Neckers L 2003 Heat shock protein 90 as a molecular target for cancer therapeutics. Cancer Cell 3 213-217.

Izbicka E, MacDonald JR, Davidson K, Lawrence RA, Gomez L \& Von Hoff DD 1999 5,6 Dihydro-5'azacytidine DHAC restores androgen responsiveness in androgen-insensitive prostate cancer cells. Anticancer Research 19 1285-1291.

Jackson TA, Richer JK, Bain DL, Takimoto GS, Tung L \& Horwitz K B 1997 The partial agonist activity of antagonist-occupied steroid receptors is controlled by a novel hinge domain-binding coactivator L7/SPA and the corepressors N-CoR or SMRT. Molecular Endocrinology 11 693-705.

Jarrard DF, Kinoshita H, Shi Y, Sandefur C, Hoff D, Meisner LF, Chang C, Herman JG, Isaacs WB \& Nassif N 1998 Methylation of the androgen receptor promoter $\mathrm{CpG}$ island is associated with loss of androgen receptor expression in prostate cancer cells. Cancer Research $\mathbf{5 8}$ 5310-5314.

Jayasuriya H, Koonchanok NM, Geahlen RL, McLaughlin JL \& Chang CJ 1992 Emodin, a protein tyrosine kinase inhibitor from Polygonum cuspidatum. Journal of Natural Products 55 696-698.

Jemal A, Murray T, Samuels A, Ghafoor A, Ward E \& Thun MJ 2003 Cancer statistics, 2003 CA a Cancer Journal for Clinicians 53 5-26.

Jemal A, Tiwari RC, Murray T, Ghafoor A, Samuels A, Ward E, Feuer EJ \& Thun MJ 2004 Cancer statistics, 2004 CA a Cancer Journal for Clinicians 54 8-29. 
Jing X, Ueki N, Cheng J, Imanishi H \& Hada T 2002 Induction of apoptosis in hepatocellular carcinoma cell lines by emodin. Japanese Journal of Cancer Research $\mathbf{9 3}$ 874-882.

Johnston SR \& Dowsett M 2003 Aromatase inhibitors for breast cancer: lessons from the laboratory. Nature Reviews Cancer 3 821-831.

Johnston SR, Head J, Pancholi S, Detre S, Martin LA, Smith IE \& Dowsett M 2003 Integration of signal transduction inhibitors with endocrine therapy: an approach to overcoming hormone resistance in breast cancer. Clinical Cancer Research 9 524S-532S.

Jordan VC $2003 a$ Antiestrogens and selective estrogen receptor modulators as multifunctional medicines. 1 Receptor interactions. Journal of Medicinal Chemistry 46 883-908.

Jordan VC $2003 b$ Antiestrogens and selective estrogen receptor modulators as multifunctional medicines. 2 Clinical considerations and new agents. Journal of Medicinal Chemistry 46 1081-1111.

Kamal A, Thao L, Sensintaffar J, Zhang L, Boehm MF, Fritz LC \& Burrows FJ 2003 A high-affinity conformation of Hsp90 confers tumour selectivity on Hsp90 inhibitors. Nature 425 407-410.

Kang HY, Yeh S, Fujimoto N \& Chang C 1999 Cloning and characterization of human prostate coactivator ARA54, a novel protein that associates with the androgen receptor. Journal of Biological Chemistry 274 8570-8576.

Kato S, Endoh H, Masuhiro Y, Kitamoto T, Uchiyama S, Sasaki H, Masushige S, Gotoh Y, Nishida E, Kawashima $\mathrm{H}$, et al. 1995 Activation of the estrogen receptor through phosphorylation by mitogen-activated protein kinase. Science 270 1491-1494.

Kato S, Masuhiro Y, Watanabe M, Kobayashi Y, Takeyama KI, Endoh H \& Yanagisawa J 2000 Molecular mechanism of a cross-talk between oestrogen and growth factor signalling pathways. Genes Cells 5 593-601.

Katzenellenbogen BS \& Katzenellenbogen JA 2002 Biomedicine: defining the "S" in SERMs. Science 295 2380-2381.

Kiang DT \& Kennedy BJ 1977 Tamoxifen antiestrogen therapy in advanced breast cancer. Annals of Internal Medicine 87 687-690.

Klinge CM 2000 Estrogen receptor interaction with co-activators and co-repressors. Steroids 65 227-251.

Koivisto PA \& Rantala I 1999 Amplification of the androgen receptor gene is associated with P53 mutation in hormone-refractory recurrent prostate cancer. Journal of Pathology 187 237-241.

Kollara A, Kahn HJ, Marks A \& Brown TJ 2001 Loss of androgen receptor associated protein 70 ARA70 expression in a subset of HER2-positive breast cancers. Breast Cancer Research and Treatment 67 245-253.

Kousteni S, Bellido T, Plotkin LI, O'Brien CA, Bodenner DL, Han L, Han K, DiGregorio GB, Katzenellenbogen JA, Katzenellenbogen BS, et al. 2001 Nongenotropic, sexnonspecific signaling through the estrogen or androgen receptors: dissociation from transcriptional activity. Cell 104 719-730.

Kumar R, Wang RA, Mazumdar A, Talukder AH, Mandal M, Yang Z, Bagheri-Yarmand R, Sahin A, Hortobagyi G, Adam L, et al. 2002 A naturally occurring MTA1 variant sequesters oestrogen receptor-alpha in the cytoplasm. Nature 418 654-657.

Kurokawa H \& Arteaga CL 2001 Inhibition of erbB receptor HER tyrosine kinases as a strategy to abrogate antiestrogen resistance in human breast cancer. Clinical Cancer Research 7 4436s-4442s; discussion 4411s-4412s.

Kurokawa H, Lenferink AE, Simpson JF, Pisacane PI, Sliwkowski MX, Forbes JT \& Arteaga CL 2000 Inhibition of HER2/neu erbB-2 and mitogen-activated protein kinases enhances tamoxifen action against HER2overexpressing, tamoxifen-resistant breast cancer cells. Cancer Research $605887-5894$.

Labrie F, Belanger A, Dupont A, Luu-The V, Simard J \& Labrie C 1993 Science behind total androgen blockade: from gene to combination therapy. Clinical and Investigative Medicine 16 475-492.

Lanz RB, McKenna NJ, Onate SA, Albrecht U, Wong J, Tsai SY, Tsai MJ \& O'Malley BW 1999 A steroid receptor coactivator, SRA, functions as an RNA and is present in an SRC-1 complex. Cell 97 17-27.

Lee SK, Kim HJ, Na SY, Kim TS, Choi HS, Im SY \& Lee JW 1998 Steroid receptor coactivator-1 coactivates activating protein-1-mediated transactivations through interaction with the c-Jun and c-Fos subunits. Journal of Biological Chemistry 273 16651-16654.

Lee WP, Liao Y, Robinson D, Kung HJ, Liu ET \& Hung MC 1999 Axl-gas6 interaction counteracts E1A-mediated cell growth suppression and proapoptotic activity. Molecular and Cellular Biology 19 8075-8082.

Levine AJ, Momand J \& Finlay CA 1991 The p53 tumour suppressor gene. Nature 351 453-456.

Li J, Yen C, Liaw D, Podsypanina K, Bose S, Wang SI, Puc J, Miliaresis C, Rodgers L, McCombie R, et al. 1997 PTEN, a putative protein tyrosine phosphatase gene mutated in human brain, breast \& prostate cancer. Science 275 1943-1947.

Liao Y \& Hung MC 2003 Regulation of the activity of p38 mitogen-activated protein kinase by Akt in cancer and adenoviral protein E1A-mediated sensitization to apoptosis. Molecular and Cellular Biology 23 6836-6848.

Liao Y, Zou Y, Xia W \& Hung M 2004 Enhanced paclitaxel cytotoxicity and prolonged animal survival rate by a non-viral mediated systemic delivery of E1A gene in orthotopic xenograft human breast cancer. Cancer Gene Therapy 11 594-602.

Lin HK, Yeh S, Kang HY \& Chang C 2001 Akt suppresses androgen induced apoptosis by phosphorylating and inhibiting androgen receptor. PNAS 98 7200-7205.

Liu MM, Albanese C, Anderson CM, Hilty K, Webb P, Uht RM, Price RH Jr, Pestell RG \& Kushner PJ 2002 Opposing action of estrogen receptors alpha and beta on 
cyclin D1 gene expression. Journal of Biological Chemistry 277 24353-24360.

Love RR, Mazess RB, Barden HS, Epstein S, Newcomb PA, Jordan VC, Carbone PP \& DeMets DL 1992 Effects of tamoxifen on bone mineral density in postmenopausal women with breast cancer. New England Journal of Medicine 326 852-856.

Lowe SW, Ruley HE, Jacks T \& Housman DE 1993 p53-dependent apoptosis modulates the cytotoxicity of anticancer agents. Cell 74 957-967.

Madhusudan S \& Ganesan TS 2004 Tyrosine kinase inhibitors in cancer therapy. Clinical Biochemistry 37 618-635.

Madhusudan S, Tamir A, Bates N, Flanagan E, Gore ME, Barton DP, Harper P, Seckl M, Thomas H, Lemoine NR, et al. 2004 A multicenter Phase I gene therapy clinical trial involving intraperitoneal administration of E1A-lipid complex in patients with recurrent epithelial ovarian cancer overexpressing HER-2/neu oncogene. Clinical Cancer Research 10 2986-2996.

Marcelli M, Ittmann M, Mariani S, Sutherland R, Nigam R, Murthy L, Zhao Y, DiConcini D, Puxeddu E, Esen A, et al. 2000 Androgen receptor mutations in prostate cancer. Cancer Research 60 944-949.

Martin AM, Blackwood MA, Antin-Ozerkis D, Shih HA, Calzone K, Colligon TA, Seal S, Collins N, Stratton MR, Weber BL \& Nathanson KL 2001 Germline mutations in BRCA1 and BRCA2 in breast-ovarian families from a breast cancer risk evaluation clinic. Journal of Clinical Oncology 19 2247-2253.

Martin LA, Farmer I, Johnston SR, Ali S, Marshall C \& Dowsett M 2003 Enhanced estrogen receptor ER alpha, ERBB2 \& MAPK signal transduction pathways operate during the adaptation of MCF-7 cells to long term estrogen deprivation. Journal of Biological Chemistry 278 30458-30468.

McLeod DG, Benson RC Jr, Eisenberger MA, Crawford ED, Blumenstein BA, Spicer D \& Spaulding JT 1993 The use of flutamide in hormone-refractory metastatic prostate cancer. Cancer 72 3870-3873.

Migliaccio A, Castoria G, Di Domenico M, de Falco A, Bilancio A, Lombardi M, Bottero D, Varricchio L, Nanayakkara M, Rotondi A \& Auricchio F 2002 Sex steroid hormones act as growth factors. Journal of Steroid Biochemistry and Molecular Biology 83 31-35.

Miki Y, Swensen J, Shattuck-Eidens D, Futreal PA, Harshman K, Tavtigian S, Liu Q, Cochran C, Bennett LM, Ding W, et al. 1994 A strong candidate for the breast and ovarian cancer susceptibility gene BRCA1. Science 266 66-71.

Mitlak BH \& Cohen FJ 1999 Selective estrogen receptor modulators: a look ahead. Drugs 57 653-663.

Morris C \& Wakeling A 2002 Fulvestrant 'Faslodex' — a new treatment option for patients progressing on prior endocrine therapy. Endocrine-Related Cancer 9 267-276.

Muss HB 1992 Endocrine therapy for advanced breast cancer: a review. Breast Cancer Research and Treatment 21 15-26.
Nahta R \& Esteva FJ 2003 Bcl-2 antisense oligonucleotides: a potential novel strategy for the treatment of breast cancer. Seminars in Oncology 30 143-149.

Nakshatri H, Bhat-Nakshatri P, Martin DA, Goulet RJ Jr, \& Sledge GW Jr 1997 Constitutive activation of NF-kappaB during progression of breast cancer to hormoneindependent growth. Molecular and Cellular Biology 17 3629-3639.

Navarro D, Luzardo OP, Fernandez L, Chesa N \& DiazChico BN 2002). Transition to androgen-independence in prostate cancer. Journal of Steroid Biochemistry and Molecular Biology 81 191-201.

Negro-Vilar A 1999 Selective androgen receptor modulators SARMs : a novel approach to androgen therapy for the new millennium. Journal of Clinical Endocrinology and Metabolism 84 3459-3462.

Nelson WG, De Marzo AM \& Isaacs WB 2003 Prostate cancer. New England Journal of Medicine 349 366-381.

Neumann F 1982 Pharmacology and clinical use of antiandrogens: a short review. Ir Journal of Medical Sciences 151 61-70.

Normanno N, Bianco C, De Luca A, Maiello MR \& Salomon DS 2003 Target-based agents against ErbB receptors and their ligands: a novel approach to cancer treatment. Endocrine-Related Cancer 10 1-21.

Osborne CK, Schiff R, Fuqua SA \& Shou J 2001 Estrogen receptor: current understanding of its activation and modulation. Clinical Cancer Research 7 4338s-4342s; discussion 4411s-4412s.

Osborne CK, Pippen J, Jones SE, Parker LM, Ellis M, Come S, Gertler SZ, May JT, Burton G, Dimery I, et al. 2002 Double-blind, randomized trial comparing the efficacy and tolerability of fulvestrant versus anastrozole in postmenopausal women with advanced breast cancer progressing on prior endocrine therapy: results of a North American trial. Journal of Clinical Oncology 20 3386-3395.

Osborne CK, Bardou V, Hopp TA, Chamness GC, Hilsenbeck SG, Fuqua SA, Wong J, Allred DC, Clark GM \& Schiff R 2003 Role of the estrogen receptor coactivator AIB1 SRC-3 and HER-2/neu in tamoxifen resistance in breast cancer. Journal of the National Cancer Institute 95 353-361.

Paech K, Webb P, Kuiper GG, Nilsson S, Gustafsson J, Kushner PJ \& Scanlan TS 1997 Differential ligand activation of estrogen receptors ERalpha and ERbeta at AP1 sites. Science 277 1508-1510.

Palmieri C, Lam EW, Mansi J, MacDonald C, Shousha S, Madden P, Omoto Y, Sunters A, Warner M, Gustafsson JA \& Coombes RC 2004 The expression of ER beta cx in human breast cancer and the relationship to endocrine therapy and survival. Clinical Cancer Research $\mathbf{1 0}$ 2421-2428.

Piccart M, Parker LM \& Pritchard KI 2003 Oestrogen receptor downregulation: an opportunity for extending the window of endocrine therapy in advanced breast cancer. Annals of Oncology 14 1017-1025. 
Pietras RJ, Arboleda J, Reese DM, Wongvipat N, Pegram MD, Ramos L, Gorman CM, Parker MG, Sliwkowski MX \& Slamon DJ 1995 HER-2 tyrosine kinase pathway targets estrogen receptor and promotes hormoneindependent growth in human breast cancer cells. Oncogene 10 2435-2446.

Pozzatti R, McCormick M, Thompson MA, Garbisa S, Liotta L \& Khoury G 1988 a Regulation of the metastatic phenotype by the E1A gene of adenovirus-2. Advances in Experimental Medicine and Biology 233 293-301.

Pozzatti R, McCormick M, Thompson MA \& Khoury G $1988 b$ The E1a gene of adenovirus type 2 reduces the metastatic potential of ras-transformed rat embryo cells. Molecular and Cellular Biology 8 2984-2988.

Qiu Y, Ravi L \& Kung HJ 1998 Requirement of ErbB2 for signalling by interleukin-6 in prostate carcinoma cells. Nature 393 83-85.

Ravdin PM, Fritz NF, Tormey DC \& Jordan VC 1988 Endocrine status of premenopausal node-positive breast cancer patients following adjuvant chemotherapy and long-term tamoxifen. Cancer Research 48 1026-1029.

Revillion F, Bonneterre J \& Peyrat JP 1998 ERBB2 oncogene in human breast cancer and its clinical significance. European Journal of Cancer 34 791-808.

Robertson JF \& Blamey RW 2003 The use of gonadotrophinreleasing hormone GnRH agonists in early and advanced breast cancer in pre-and perimenopausal women. European Journal of Cancer 39 861-869.

Robertson JF, Nicholson RI, Bundred NJ, Anderson E, Rayter Z, Dowsett M, Fox JN, Gee JM, Webster A, Wakeling AE, et al. 2001 Comparison of the short-term biological effects of 7alpha-[9-4.4,5,5,5pentafluoropentylsulfinyl-nonyl]estra-1,3,5,10-triene3,17beta-diol Faslodex versus tamoxifen in postmenopausal women with primary breast cancer. Cancer Research 61 6739-6746.

Roodman GD 2001 Biology of osteoclast activation in cancer. Journal of Clinical Oncology 19 3562-3571.

Ropke A, Erbersdobler A, Hammerer P, Palisaar J, John K, Stumm M \& Wieacker P 2004 Gain of androgen receptor gene copies in primary prostate cancer due to $\mathrm{X}$ chromosome polysomy. Prostate 59 59-68.

Rosen EM, Fan S \& Goldberg ID 2001 BRCA1 and prostate cancer. Cancer Investigation 19 396-412.

Rossouw JE, Anderson GL, Prentice RL, LaCroix AZ, Kooperberg C, Stefanick ML, Jackson RD, Beresford SA, Howard BV, Johnson KC, et al. 2002 Risks and benefits of estrogen plus progestin in healthy postmenopausal women: principal results from the Women's Health Initiative randomized controlled trial. Journal of the American Medical Association 288 321-333.

Ruijter E, van de Kaa C, Miller G, Ruiter D, Debruyne F \& Schalken J 1999 Molecular genetics and epidemiology of prostate carcinoma. Endocrine Reviews 20 22-45.

Salgado R, Junius S, Benoy I, Van Dam P, Vermeulen P, Van Marck E, Huget P \& Dirix LY 2003 Circulating interleukin-6 predicts survival in patients with metastatic breast cancer. International Journal of Cancer 103 642-646.

Santen RJ, Song RX, Zhang Z, Kumar R, Jeng MH, Masamura S, Yue W \& Berstein L 2003 Adaptive hypersensitivity to estrogen: mechanism for superiority of aromatase inhibitors over selective estrogen receptor modulators for breast cancer treatment and prevention. Endocrine-Related Cancer 10 111-130.

Schiff R, Reddy P, Ahotupa M, Coronado-Heinsohn E, Grim M, Hilsenbeck SG, Lawrence R, Deneke S, Herrera R, Chamness GC, et al. 2000 Oxidative stress and AP-1 activity in tamoxifen-resistant breast tumors in vivo. Journal of the National Cancer Institute 92 1926-1934.

Schiff R, Massarweh S, Shou J \& Osborne CK 2003 Breast cancer endocrine resistance: how growth factor signaling and estrogen receptor coregulators modulate response. Clinical Cancer Research 9 447S-454S.

Schiff R, Massarweh SA, Shou, J, Bharwani L, Mohsin SK \& Osborne CK 2004 Cross-talk between estrogen receptor and growth factor pathways as a molecular target for overcoming endocrine resistance. Clinical Cancer Research 10 331S-336S.

Segnitz B \& Gehring U 1997 The function of steroid hormone receptors is inhibited by the hsp90-specific compound geldanamycin. Journal of Biological Chemistry 272 18694-18701.

Shao R, Karunagaran D, Zhou BP, Li K, Lo SS, Deng J, Chiao P \& Hung MC 1997 Inhibition of nuclear factorkappaB activity is involved in E1A-mediated sensitization of radiation-induced apoptosis. Journal of Biological Chemistry 272 32739-32742.

Shao R, Hu MC, Zhou BP, Lin SY, Chiao PJ, von Lindern RH, Spohn B \& Hung MC 1999 E1A sensitizes cells to tumor necrosis factor-induced apoptosis through inhibition of IkappaB kinases and nuclear factor kappaB activities. Journal of Biological Chemistry 274 21495-21498.

Shao R, Tsai EM, Wei K, von Lindern R, Chen YH, Makino K \& Hung MC 2001 E1A inhibition of radiation-induced NF-kappaB activity through suppression of IKK activity and IkappaB degradation, independent of Akt activation. Cancer Research 61 7413-7416.

Smith CL, Nawaz Z \& O’Malley BW 1997 Coactivator and corepressor regulation of the agonist/antagonist activity of the mixed antiestrogen, 4-hydroxytamoxifen.

Molecular Endocrinology 11 657-666.

Solit DB, Basso AD, Olshen AB, Scher HI \& Rosen N 2003 Inhibition of heat shock protein 90 function downregulates Akt kinase and sensitizes tumors to Taxol. Cancer Research 63 2139-2144.

Speirs V, Malone C, Walton DS, Kerin MJ \& Atkin SL 1999 Increased expression of estrogen receptor beta mRNA in tamoxifen-resistant breast cancer patients. Cancer Research 59 5421-5424.

Speirs V, Carder PJ, Lane S, Dodwell D, Lansdown MR \& Hanby AM 2004 Oestrogen receptor beta: what it means 
for patients with breast cancer. Lancet Oncology 5 174-181.

Spencer TE, Jenster G, Burcin MM, Allis CD, Zhou J, Mizzen CA, McKenna NJ, Onate SA, Tsai SY, Tsai MJ \& O'Malley BW 1997 Steroid receptor coactivator-1 is a histone acetyltransferase. Nature 389 194-198.

Srinivas G, Anto RJ, Srinivas P, Vidhyalakshmi S, Senan VP \& Karunagaran D 2003 Emodin induces apoptosis of human cervical cancer cells through poly ADP-ribose polymerase cleavage and activation of caspase-9. European Journal of Pharmacol 473 117-125.

Suen CS, Berrodin TJ, Mastroeni R, Cheskis BJ, Lyttle CR \& Frail DE 1998 A transcriptional coactivator, steroid receptor coactivator-3, selectively augments steroid receptor transcriptional activity. Journal of Biological Chemistry 273 27645-27653.

Suh N, Glasebrook AL, Palkowitz AD, Bryant HU, Burris LL, Starling JJ, Pearce HL, Williams C, Peer C, Wang Y \& Sporn MB 2001 Arzoxifene, a new selective estrogen receptor modulator for chemoprevention of experimental breast cancer. Cancer Research $\mathbf{6 1}$ 8412-8415.

Suzuki H, Ueda T, Ichikawa T \& Ito H 2003 Androgen receptor involvement in the progression of prostate cancer. Endocrine-Related Cancer 10 209-216.

Taplin ME, Bubley GJ, Shuster TD, Frantz ME, Spooner AE, Ogata GK, Keer HN \& Balk SP 1995 Mutation of the androgen-receptor gene in metastatic androgenindependent prostate cancer. New England Journal of Medicine 332 1393-1398.

Teutsch G, Goubet F, Battmann T, Bonfils A, Bouchoux F, Cerede E, Gofflo D, Gaillard-Kelly M \& Philibert D 1994 Non-steroidal antiandrogens:synthesis and biological profile of high-affinity ligands for the androgen receptor. Journal of Steroid Biochemistry and Molecular Biology 48 111-119.

Thompson IM, Goodman PJ, Tangen CM, Lucia MS, Miller GJ, Ford LG, Lieber MM, Cespedes RD, Atkins JN, Lippman SM, et al. 2003 The influence of finasteride on the development of prostate cancer. New England Journal of Medicine 349 215-224.

Treuter E, Albrektsen T, Johansson L, Leers J \& Gustafsson JA 1998 A regulatory role for RIP140 in nuclear receptor activation. Molecular Endocrinology 12 864-881.

Ueno NT, Yu D \& Hung MC 1997 Chemosensitization of HER-2/neu-overexpressing human breast cancer cells to paclitaxel Taxol by adenovirus type 5 E1A. Oncogene $\mathbf{1 5}$ 953-960.

Villaret D, Glisson B, Kenady D, Hanna E, Carey M, Gleich L, Yoo GH, Futran N, Hung MC, Anklesaria P \& Heald AE 2002 A multicenter phase II study of tgDCC-E1A for the intratumoral treatment of patients with recurrent head and neck squamous cell carcinoma. Head Neck $\mathbf{2 4}$ 661-669.

Wakeling AE \& Bowler J 1988 Novel antioestrogens without partial agonist activity. Journal of Steroid Biochemistry 31 $645-653$.
Wakeling AE, Dukes M \& Bowler J 1991 A potent specific pure antiestrogen with clinical potential. Cancer Research $513867-3873$.

Wang X, Yeh S, Wu G, Hsu CL, Wang L, Chiang T, Yang Y, Guo Y \& Chang C 2001 Identification and characterization of a novel androgen receptor coregulator ARA267-alpha in prostate cancer cells. Journal of Biological Chemistry 276 40417-40423.

Weryha G, Pascal-Vigneron V, Klein M \& Leclere J 1999 Selective estrogen receptor modulators. Current Opinions in Rheumatology 11 301-306.

Williamson JG \& Ellis JD 1973 The induction of ovulation by tamoxifen. Journal of Obstetrics and Gynaecology British Commonwealth 80 844-847.

Wold WS 1993 Adenovirus genes that modulate the sensitivity of virus-infected cells to lysis by TNF. Journal of Cellular Biochemistry 53 329-335.

Wong ZW \& Ellis MJ 2004 First-line endocrine treatment of breast cancer: aromatase inhibitor or antioestrogen? British Journal of Cancer 90 20-25.

Wooster R \& Weber BL 2003 Breast and ovarian cancer. New England Journal of Medicine 348 2339-2347.

Workman P 2004 Combinatorial attack on multistep oncogenesis by inhibiting the Hsp90 molecular chaperone. Cancer Letters 206 149-157.

Xu J, Liao L, Ning G, Yoshida-Komiya H, Deng C \& O'Malley BW 2000 The steroid receptor coactivator SRC-3 p/CIP/RAC3/AIB1/ACTR/TRAM-1is required for normal growth, puberty, female reproductive function and mammary gland development. PNAS 97 6379-6384.

Xu J, Qiu Y, DeMayo FJ, Tsai SY, Tsai MJ \& O’Malley BW 1998 Partial hormone resistance in mice with disruption of the steroid receptor coactivator-1 SRC-1 gene. Science 279 1922-1925.

Yeh S \& Chang C 1996 Cloning and characterization of a specific coactivator, ARA70, for the androgen receptor in human prostate cells. PNAS 93 5517-5521.

Yeh S, Miyamoto H, Shima H \& Chang C 1998 From estrogen to androgen receptor: a new pathway for sex hormones in prostate. PNAS 95 5527-5532.

Yeh S, Kang HY, Miyamoto H, Nishimura K, Chang HC, Ting HJ, Rahman M, Lin HK, Fujimoto N, Hu YC, et al. 1999 Differential induction of androgen receptor transactivation by different androgen receptor coactivators in human prostate cancer DU145 cells. Endocrine 11 195-202.

Yeh S, Hu YC, Rahman M, Lin HK, Hsu CL, Ting HJ, Kang HY \& Chang C 2000 Increase of androgen-induced cell death and androgen receptor transactivation by BRCA1 in prostate cancer cells. PNAS 97 11256-11261.

Yoo GH, Hung MC, Lopez-Berestein G, LaFollette S, Ensley JF, Carey M, Batson E, Reynolds TC \& Murray JL 2001 Phase I trial of intratumoral liposome E1A gene therapy in patients with recurrent breast and head and neck cancer. Clinical Cancer Research 7 1237-1245.

Yu D, Suen TC, Yan DH, Chang LS \& Hung MC 1990 Transcriptional repression of the neu protooncogene by 
the adenovirus 5 E1A gene products. PNAS 87 4499-4503.

Yu DH, Scorsone K \& Hung MC 1991 Adenovirus type 5 E1A gene products act as transformation suppressors of the neu oncogene. Molecular and Cellular Biology 11 1745-1750.

Yu D, Shi D, Scanlon M \& Hung MC 1993 Reexpression of neu-encoded oncoprotein counteracts the tumorsuppressing but not the metastasis-suppressing function of E1A. Cancer Research 53 5784-5790.

Yue W, Santen RJ, Wang JP, Hamilton CJ \& Demers LM 1999 Aromatase within the breast. Endocrine-Related Cancer 6 157-164.

Yue W, Wang JP, Conaway MR, Li Y \& Santen RJ 2003 Adaptive hypersensitivity following long-term estrogen deprivation: involvement of multiple signal pathways. Journal of Steroid Biochemistry and Molecular Biology 86 265-274.

Zhang L \& Hung MC 1996 Sensitization of HER-2/neuoverexpressing non-small cell lung cancer cells to chemotherapeutic drugs by tyrosine kinase inhibitor emodin. Oncogene 12 571-576.

Zhang L, Chang CJ, Bacus SS \& Hung MC 1995 Suppressed transformation and induced differentiation of HER-2/neu-overexpressing breast cancer cells by emodin. Cancer Research 55 3890-3896.

Zhang L, Lau YK, Xia W, Hortobagyi GN \& Hung MC 1999 Tyrosine kinase inhibitor emodin suppresses growth of HER-2/neu-overexpressing breast cancer cells in athymic mice and sensitizes these cells to the inhibitory effect of paclitaxel. Clinical Cancer Research 5 343-353.

Zhi L, Tegley CM, Marschke KB \& Jones TK 1999 Switching androgen receptor antagonists to agonists by modifying $\mathrm{C}$-ring substituents on piperidino[3,2-g]quinolinone. Bioorganic \& Medicinal Chemistry Letters 9 1009-1012.

Zhi L, Tegley CM, Pio B, West SJ, Marschke KB, Mais DE \& Jones TK 2000 Nonsteroidal progesterone receptor antagonists based on 6-thiophenehydroquinolines. Bioorganic and medicinal chemistry letters 10 415-418. 